のいは顕わのでで庭段和概る

現て、在が展あはだ階息。現 実を語化国開りあけに方鈴時 の不るし資に、るをな松峻木、小 生明とて本つそが抽つ原別栄社 活確こい主いれ、象て治し太会 過なろる義てよし化い郎た郎学 程点が階社はりかしる意がに そがあ級会な生し、。副味馬お

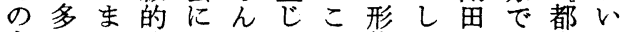
もいり諸おらてん態か義生市て の。に矛け子くにのし染社生 をさも盾るれるち整す椑会活 おになま民れの社をでた概原造 し生いたのてが会守に園念理論 て産。国全い何でる一田を㳊 生諸ま民生なな、段番恭提こ関 産関たの活い2のそ階ヶ一示二村 諸係社そのしかので瀬らし九る 関概会の社ととなは康のた五論 係念構矛会評、加尔生段声議 自亡造盾的与うのきが活階にが 体の概止再る序基わ構と俄 が関念揚生よ列本めそ造比お加 変連々過産亏市的てれ論較てに 革「の程過にるな見はがして高 さ関に程、认要事生輩て社ま 序

れ諸連つの珲は矛が整活出、素構て

成 他特活必いそ舞 要て 的ほ性で集副果他い徽構要でれにう 事通生势団副導方意古論あでは心近所 のう活し文は入副味るはる社上現 研事構飞华述乙思思。会鈴状社

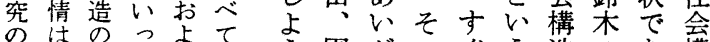
た、理てびいう園がのぐう造のあ構 めマ論を公ると田き意れ積概生る成

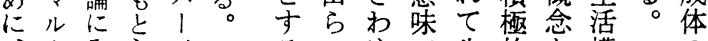

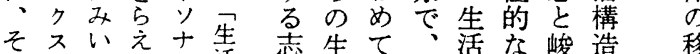
こ主だらり活 で義せれテ構 社るな1造 生会占以の研 構のい場か的莱究 理合之現理必 理でる奉論要 論をこがので 必 5 むわる 要れで、ばと とるきそ守い さ。る机備う れい:老範こ てく就整と るかう之極は 。热哥限 そ社会方能流 向活強実体提別概 性構く体系言し念

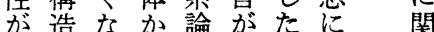
み論っらとあ意は夺 らにて離しつ味 れは、れてたで資論 る、るた収が実本点 小岩布 、。分斂、体主に ル晳さ近と義つ ク用れ時し社い 主具て它青の会它 主 具て

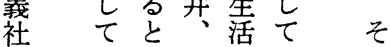

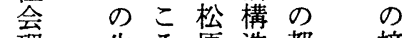
理生乃原造都接 林 城 施

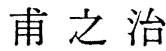




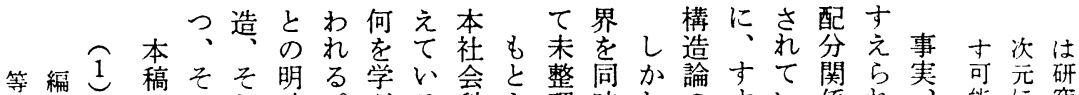

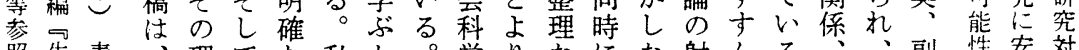
照生青、理てな私か。学りなにな射んる副性安対 の活井か論さ接達としが私大指が程で。生さ田在易象

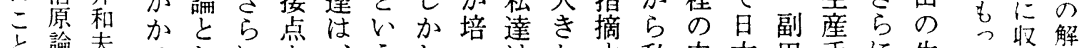

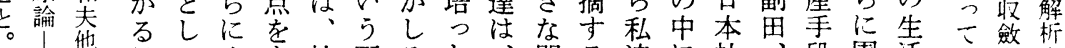
編目て生も社再々た、問る達に社、段園活い壁

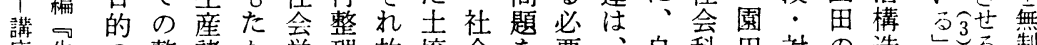
座生の整諸な学理故壌会を要、自科田対の造。る制

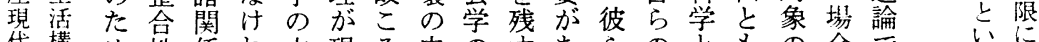

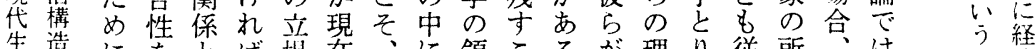

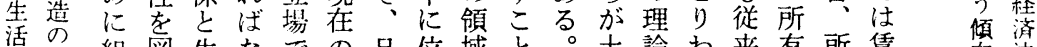
研理組図生なでの日位域と。土論わ来有所賃向法 究論まら産らの段本直のにそ台構けの関得金に則

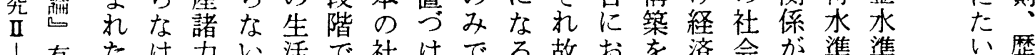

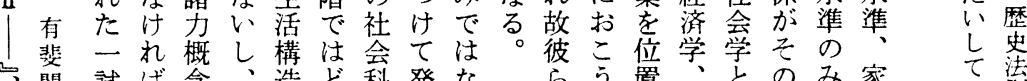

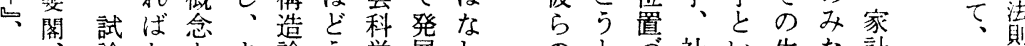

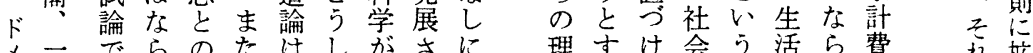

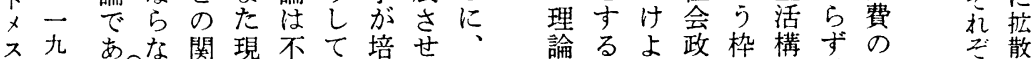
出七る敌連段可屯つるそ, 理う策の造階分机さ 版年。と性階欠必た必れの論と学中心級析㐘せ

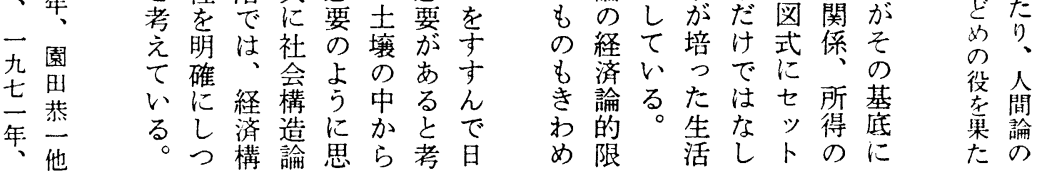

しの単をあ人社ふの生営立方

よは生位抒る。行而ま中活家論現 。め構あここ為倸て物財計そ会社 両に造る後のレ、、的の構の構会 者機論世者さ心゙集そレ配造両造学 と能の带はいル団こべ直ま方変の も主共を生前にとにル等でが革生 、義通之活者まい時をにお存論活 そ派ののの注でつ間もみり拔構 のの性戦物規子た、射らたるき造 生生格略的範か所空程れ射がの論 活活が的基、く謂間にる程、資に 構構看分盤役射、収如、前本は 造造取析を割程社いめく青者主 の論さの重、を会うて、羊の義前 論をれ焦視社打学軸认国図立的述 理る点方会万固をる战式埸経の を青。にる関し有配。のでに済如

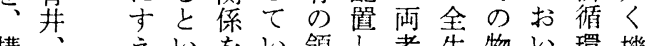
構六々をい領し者生物い環機 造松るう乔る域なと活財て論能 的原と相しとをがもの体も的主 要を違たこ金らか社采、階義

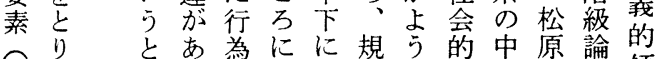

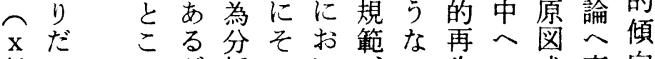

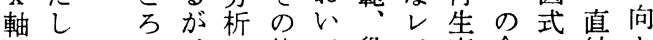
てに、に特て役心゙産金で結と 々検雨家重徽割ル過銭の経た他

第 社視 鉄は艺 $\overparen{3}$ 号

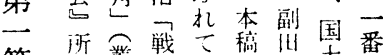

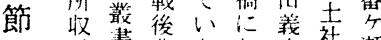

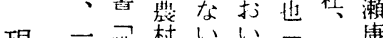
現元戦村い社。坐一康 時 七後社私活九子

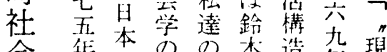

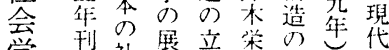
学行社開晹太基三的 に哣上か郎碳三家 お堡社辰占、理政

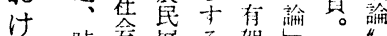

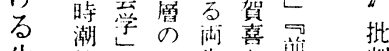
生社等 1 先在闹判

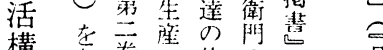
構参卷原位の有含 造照学社㗢婜告翡社 の扎会生に活灌全 検 た生告関造四教

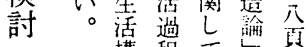

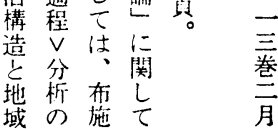


せかるあい雑こそ生機造

る゙に時らたと然を構の能要こ

を人間かとし指造再要素で

得類をにえて摘を生素とは

な史同範ばいし維産と措第

的然疇 $\mathrm{x}$ て

生発でが軸全おす体定しに

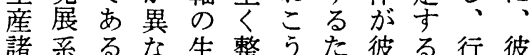

関列。る活理。めらこ為ら

係の彼。時さそにのとつが

に中ら空間れし機いで青時

よでの間年てて能うあ井間

つのいは生い第す構きさ

て生うひ活な手々る造ら精空

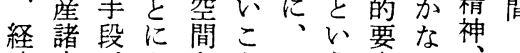

済力、と と $\mathrm{x} 5$ 素よ 手

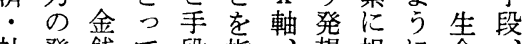

社発銭て段指、想規に命

会展、有、摘 $\mathrm{y}$ が定、の金

的段地限金し軸基さ諸再銭 に階位の錢なに底れ行生

規に自役けなにる為産役 定基役自割れ点存。等割

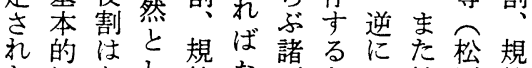
たにあし範な要とい精原範 要照きて

理為さ範物あしり、

的自机情財 文で、青機原

為的機報系、井能

遂能儿へ一の的場

が行的 | 金九場要合

設行要卜銭七合素

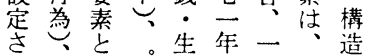

れ、迁染段九物的

て I ! 盗階六質要

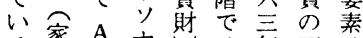

る家 $\mathrm{A}+\underbrace{\circ}$ 年再 索

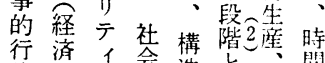

行為的体会造上精䦗

相為系采要一神空

豆融生役素九西䦐

融会铦割状 二生手

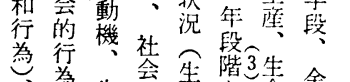

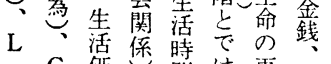

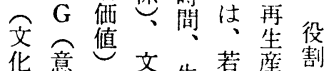

化意志文生若䧹

行決し体萿の市規

為定元采間想範

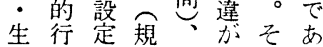

あり機

万

ᄂ 的

加要

\& 素

T $\mathrm{y}$

パ 軸

ソ間

ンの

ズマ

の

A リ

G ッ

I ク

威之

式 L

之示

ब

根と

这安

に

おに

共特

通徵

性 が

があ
社た個中と得過同の、ら

会社人かにしな程時社れ私 造構現る着存もとそ的生 は 概造実意せ寸のおう再、産、 念をの味ざるでしし生諸生 で変生にる以あてた産、関活 抽革活おを上る、階過係を 象せ過い得、こ人級程、下根 すざ程てなそとび的をに底 るるを、いの的な拉に 実をとそも矛它規台いお 体得お机の盾しそ定にてく はな乙自とのての抄と 、以て身考止具階亏級以 生も人元揚体級けな。” 活のび階る過的的なけ階た 過とと級。程に矛がれ層場 程しは的は人盾らば的合 概て、矛社びををなに 念あそ盾会と一そら規少 でるのの過の歩のな定な 抽。生る 程生で生いさく

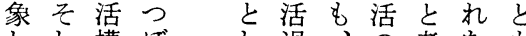
しし構ぼ過、の考たも うて造の て程止社え諸そ るこ社が揚会る個れ レのそに会社せ的。人自 ベ場しあ構会ざ再しの体 ル合てる造過る生か生与与 とのま諸の程を産し活、え
、底いか原がるらる嫢いで うにる。もあ。諸定らあ とお。こコりた彼要さ手る こく永、しら素机段 ろとか古生生かの委て特 にいしく活命に生ちい金活 あっ問てとの青活りる銭時 るた題新をた井のばか、間 場はし何えは捉めが役 合、い何ざるえる問割生 加命加氙方こ題活 如よ題上更生活兵規空 何らによ新惉焦息笽間 なな、のの点体れ等を る形私よ過根㤎、るの問 論で達生程底十前べ要題 理位は生が留分述き素に を置常活あに注に心でにす

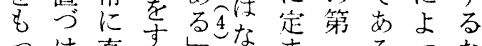
つけ直るしなま一ろつな

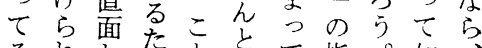
それした六て指。如 れるていをるい摘か何そ をついに指てなとなにの 裏生る兮如摘をていあ階あ 毠。何卞生こわに級り け以るにる命とせ範方 るをとにす命を考疇階が か之述すまの意えの節彼 、のべべた維味る異的ら と基てき松持玄ななにの 


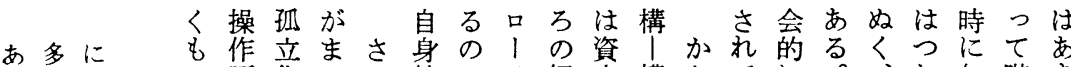

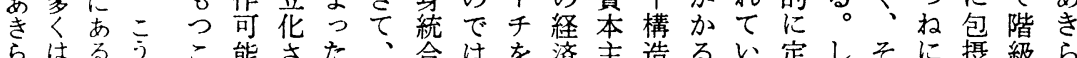
らはるうこ能さた、合はを済主造るい定しそに攝級ら か行もしとなれく前さな経構義矛意る着かれそし的加 と為のたにもた不述れく済造的プ味としも自のて規に な体老現なのへ十のた、機の経口に私た後体中い定範

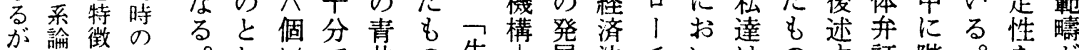

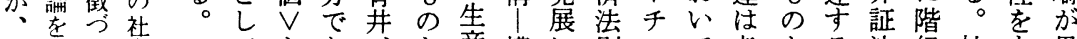
三媒け会てをあると産構に則のて考をる法級社も異 者介る学可基る松し諸造規|レ把よ的的会つな

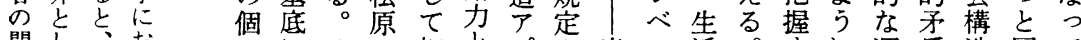
関 し、损 連て穴 は生机る き活は生 わ構た活 め造し 構 て概 か造 不念にに 十老社関 分措会卞 で定構る あし 造 機 。念主 そとと義 机しの的 らて 対な 生小店発 活 るの睡 造 学基

のにその把とプさ当ル活

$\wedge お し$ 生握生口机然過 生いて活さ産!た倠異程 活た結構れ諸チも祭との方る 把生の論必係々で経。造 握活上に要のうあ済そ予。 と、こ揖哥、る機しプ 心把ろ、あ盾こが構て口 う握、てるしのこ喜後 傾乞れは学論者の格述 をたはかえ理はレとよレ きが資かるのばべしうべ わっ本る。中らルてにル めてに点に注でも、と て資よの 色本っ整
守に運盾造同て る、動を洼い に今法も何にる は日則つよ のを、り諸 社 不段\& 可階つわ奏人構 欠で構ば体の造 には造階概階そ 社、と級念級れ 会そし的と的自 構力把関て盾は 概関握係、此、 念係守がし揚諸 がのる基か過個 必中必本\&程人 要で要にそをに と社茂貫れ同と

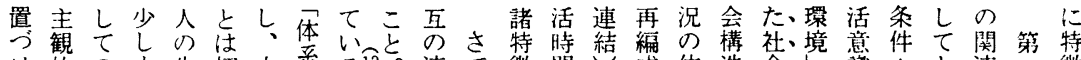

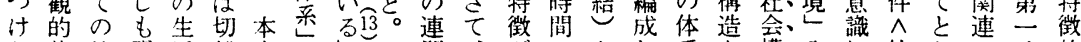

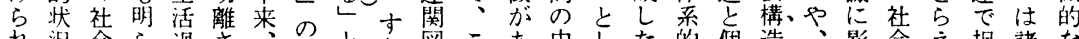

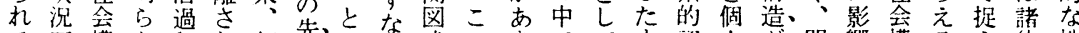

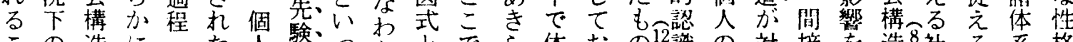
この造にたた人験っっちとでら体おの㵶の対接を造社る系格

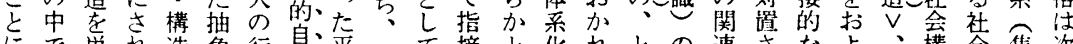
にで単れ造象行眀、平つて摘と化れとの連さなよ、構会集次

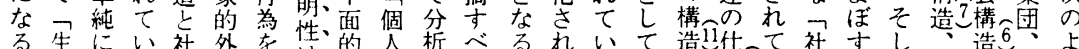

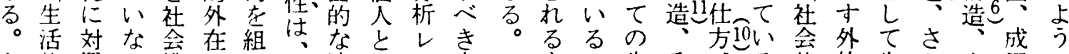

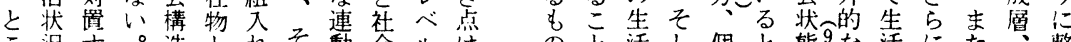

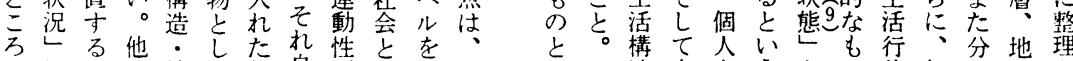

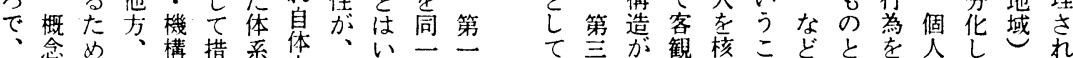
諸艻に第と定に完そずにに

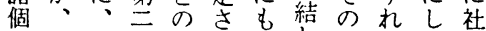
人両そに并机加発もて会 の構のは証るかた想シいな 生造構、法こわ自のスる生

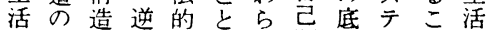
過媒下になにず運にムとの 程介で、関な、動あとが両 炎的客連る。社索るし、、構

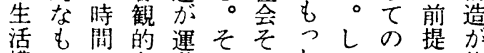
構の的条動气机たた類と体 造とき件自で自即が似さ采 そ乞り。体は体物っ性机論 犰てと存と、は性てをて的 自、り在し諸行老々壬小な 体位ととて個為示のつる相

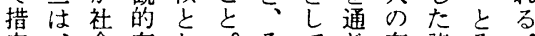
定之会存し。そて存諸々 さ構在たしこの老禁机 てしとし1がは外活主曆孝 いたのてりつつ的意㡷と立 る対対の十て权規践化諸体 と応応社儿、に制加せ集的

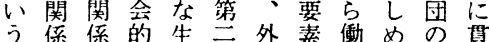
う係倸的生志外素働め関買 乏生対況体、的一加係< 。活立を系そに直けるの行 か空・主分規接た客網為 上閪関観生し定的り観の体 う年的活たさ生、的目系 な生・に状社机活生諸とと 
体と史て課論た置人界领界り行えとにさ題す内的が

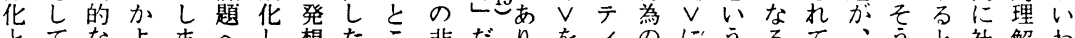

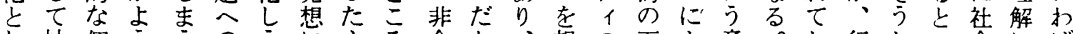
し抽個ううのうに街ろ合と、想の再よ意。し行しい会にば て出体に。主るな体で理のし定根生る味青要為たへ構対不 のさり 体十る性之的べたし本産状か井うと結た造市可 志机個气的分。の第なるが、的過況らがたい果立分る避 向る人で関なっ強三奏とつそ变程の、サめう論析不的

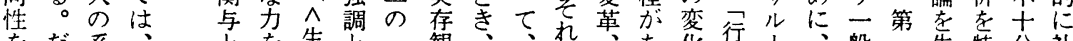

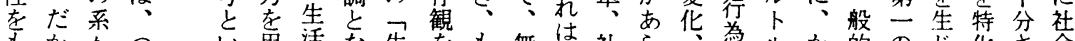
もかない前活な生をも無は社ら粱為ルか的のじ化さ会

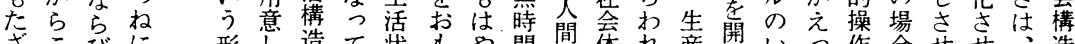

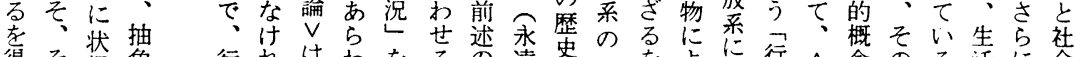
得之況象行れはわをるの遠史再をよに行へ点のる活に なの的的ばそれ媒。体造考得るお為個念抽。活に会

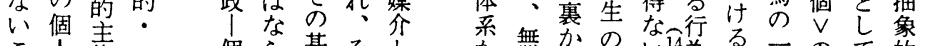

こ体般個な基々主 に実は的帆方主る な存二な対しお体立 る的孤個応と心化論 内立人 面立が 华た措 と聖等 関いてのは 係う、た、 に場生め外 を域机は行境件件 にに、矮政の創の 状あそ少的改出変 況るの 的個 超 化な造と容 主人歴机策理っ対

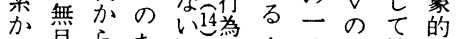
ら貝的支めと相実の塞抽個

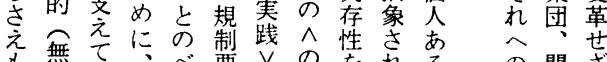

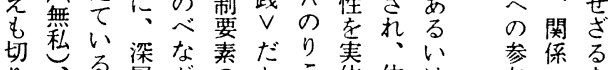
りる層がのとこ体体は与レを

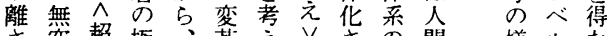
さ空超極、革え

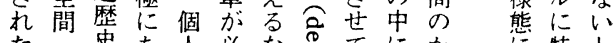

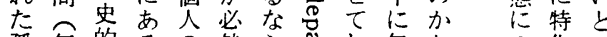
孤無的るの然ら者し包加の化心 立限 $\vee \wedge$ 八化 $\wedge$ 品含わみしう

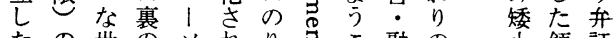

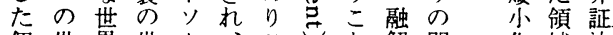

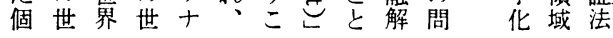

非る

所。气直造! 構党識へ自は明合明活ら合さ造さか係れ

有副こ線の社造当せさ裸明状に先さ体しと机連机ら方るそ に田乃的咅会に然さ㧈の性況㷌せれ系はしう関る17与形複の もはでな論構具なるれ、が的着のよ内してるの。え式合場

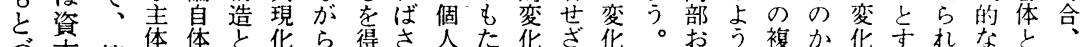

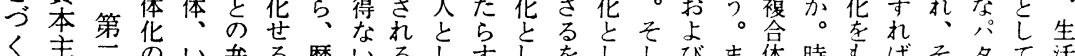

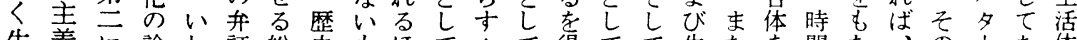

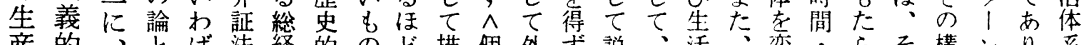

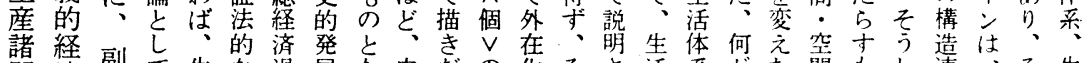
関済副て生な過展な皮だの华そさ活采がた間もし連々そ生

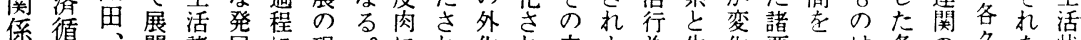
概環、開諸展に現。に化れ中ょ為生化要二は各のクを状 念の園さ相過規段 の中田ざ体程定階 中にの采論れ拉 に場变的理つい

生ま合得開考? 瑇園問心炛全独現 造田題急瓷落息存 論ははと時し規在 を生よ考にた定守 位産りえ生之綮経 置手整る。活うか経 けのさ況し寺機 よ所机対生飧構 々有て 驽澢機経 もさ的たでう萿孝素っ、合今複況 体る的。通環ものの時ラ後不合に 采老内の説だじ境た分外間 机得华と盟がたの関し解在的多変にたる 自、笑てえそ部倸たな数空のは構しそ

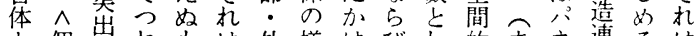

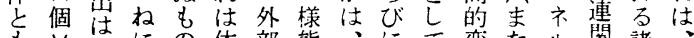

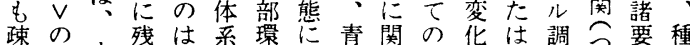
遠生まる。市境み开倸之各査ま素令

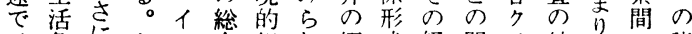
矛危にとシ。命規机概式経関亏結シの諸 盾機向只的制る念的過倸 しが抽時ク枠要変をな的で多に肴倸因 た抗象に卜組素化使説変、!ま少なか

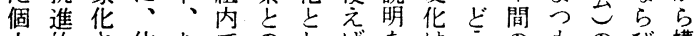
人的さ体あでのしばをはうのものび構 をに机采るの組て、も、説しの解に成 自意たのい説み説生た総明構と明関さ 


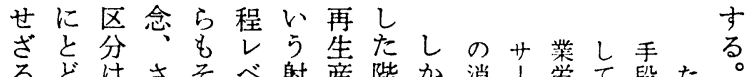

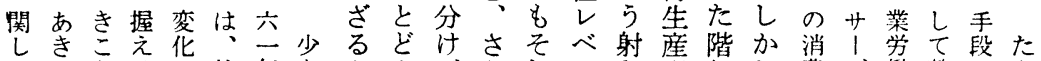

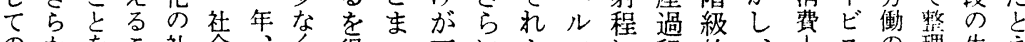

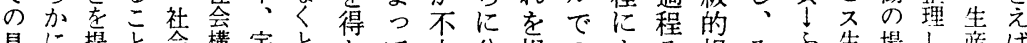

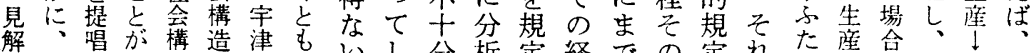
は生しで造と栄、いし分析定経での定れた䧹合さ生副

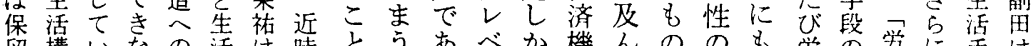
留構いなの活は時とうあべか機んののも労の学に手は さ造るい逆構アのにかるルえ構でが中か㗢生働资段生 れとがと作造メ社な、。がさ、い不でか力産力本の活

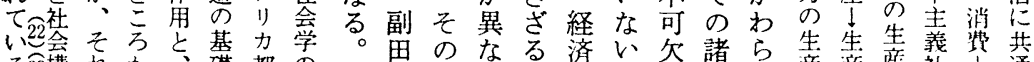
る構机か、礎都の 造は方々的市生 と提結 理 社活 の唱果背解会 構 概だ卞後の学 造 念ける记に誤 の論 老にしあり機に わ終とるか能限

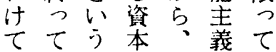
いい形のお的い るるで運け傾う が。、動て向な 、両の\&を老 そた概諸生批落 の副念機 活 判 加田在能構しす かの峻老造てで わ場別正上尼

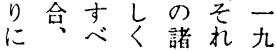

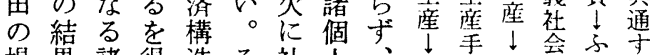
場果諸得造そ社人、さ段労会なる 合個な変こ会の副的。働生た要 園人い動でを舆田じサ活び素 生田の社のは構体、と!の满生在

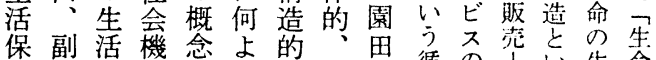

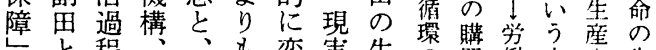

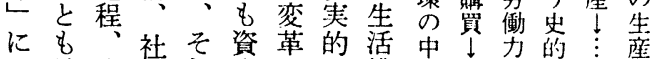
生結生会れ本せな構に生の限 活局活構に主ざ全造位活消定々生

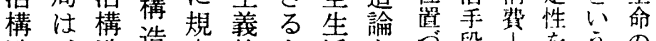

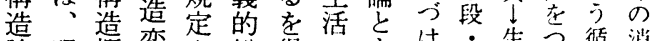

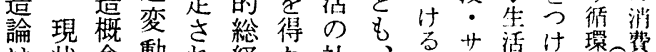

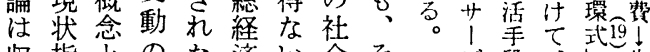

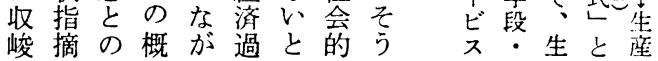

観とと論こ場試構しすその諸な第会济論は階の 点いめのにに現造な即るれ生関く兰的循にあ級循諸 をらて起は立は在分けちちこを活係とに学環結る関環個 そ事い点少っ、析れ、を規過概も働にびま係の人 の態るをなた社日、壮以淀程念一生|おついの中の 土のがそか研会本のな上でし㹸に国産生けく。中に生 壤も、のら究学社、領ら孝きかかよし手活るわしに位活 にとし多ぬ史者先会域なたなえかっべ段の社けか位置を もでかく間整の科がい前いするてルのカ侌でし置ゔ つ形しは題理み学、存社者。レ諸抽で所テ的は、势沟 て成可戦点もな発す会と関象の有ゴ生な経けて質 いさ国時が輩ら展るる構後ル係さ総!少産い済て、的 るれ民下出ずの。造者をに体非|「。学把さな 。た生のるし、中構ようと所は流第的握ら基 労活大よて社に問間成了るし有は通二手吉に盤

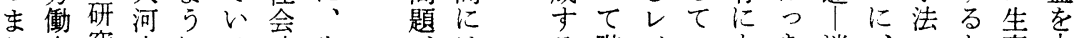
り力究内にる政生法る階べのもき消、・と産主

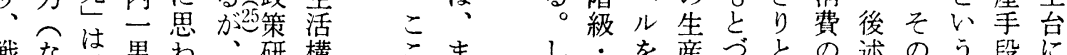

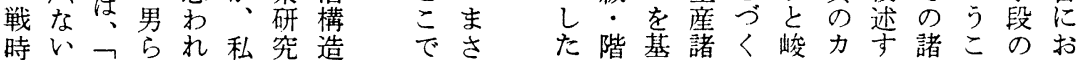

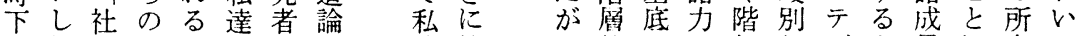
体作会ᄀ。の名薘社つ的にの級しゴよ果に有て 制業的国す立ら位の会てにお発的なりらが買|

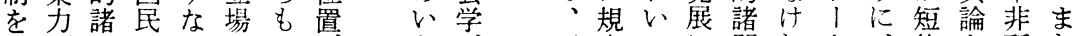

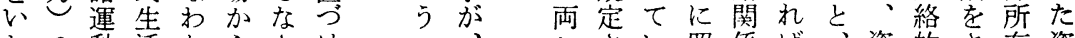
わの動萿ちらさけ只りさい照倸代、資的さ有資 ば保研、み机よ社そ心゙れる応な諸本にしに本 常護の究生る、ら会の次法主生はも主 数と終に活とそと機主学し諸た机な義萿さと義 にい緗に構、の亦構題混か個生はいの的過むう経

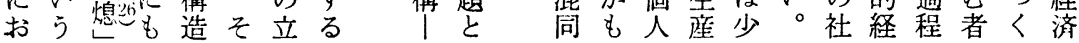




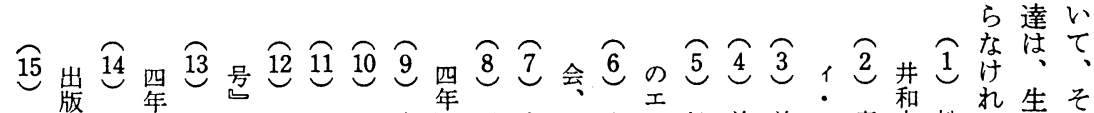
青会青青一柴雪高青雪倉一高不松前前ア青替松ば活れ 开茾二茾九野江橋井五江渠九橋プ原揭揭プ井他原な過を

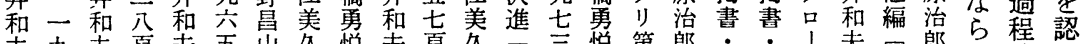

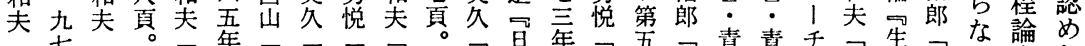

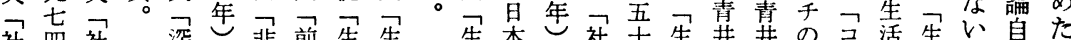
社四社梁韭前生生生本社士生并并のコ活生い自た 会年会四行䭫活活活の一会三活論論理ミ構活。体上

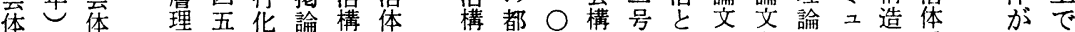

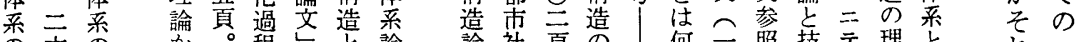

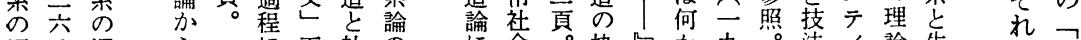

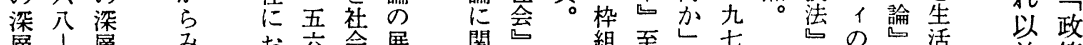

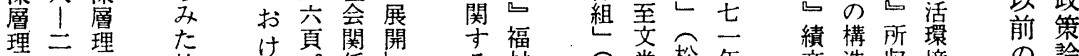

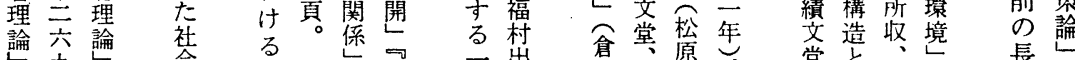

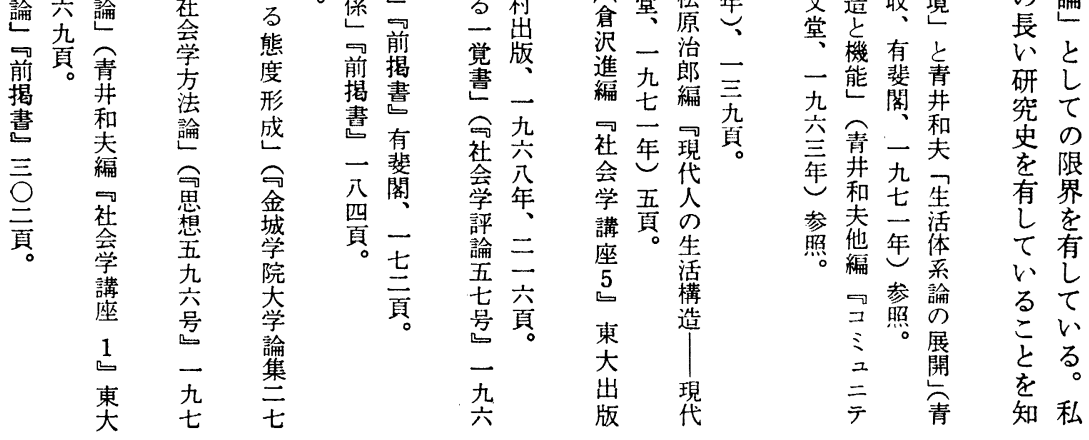

資 本 次

主の達

義占の

成に場

過整汃節

第

程 理 ら

にさ生 日

おれ活

け 5一過

るる点程 社

諸第論科

盾一第一位学

の、期置

労明け

㗢 治 る

者六 と

生 年 そ

活以れ

状降は

況 の 段

$\checkmark$ 特 階

ベ殊 的

ル日に

か本お

ら産お

の業よ

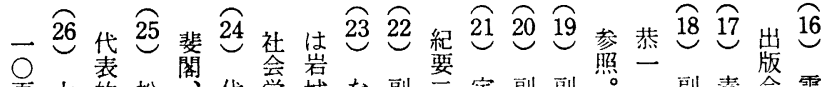
員大表的松閣代学城な副要宇副副照—副青会雪

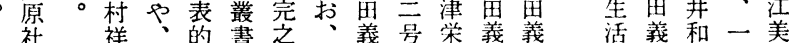
祛子袁な第子戦也祐也也

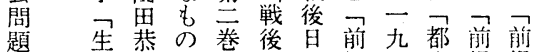

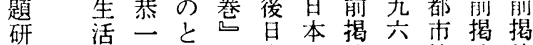
究研二し 時本都論一社論論 所究前飞潮都市文年会艾文

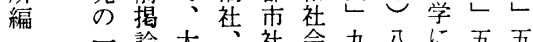

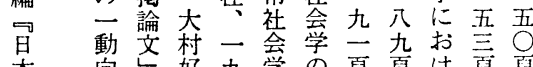
本向台恏九学の頁頁什頁頁。 㿥しが久七の分 蘍揱る生年分析梘

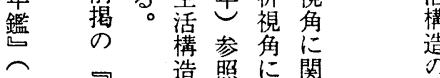
九 生 概照関祭告諸

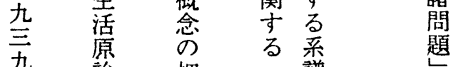

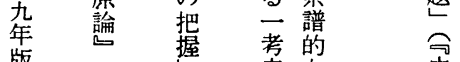

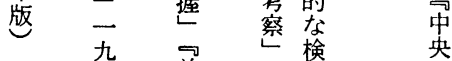
二 九 前煎倹 关 四年畫擖令齐

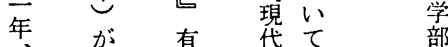

構也夫九久 造生生导生 周活活年活 園 構 構৬構 共造造六造 港造告九 他基理 頁生 編礎論 活 星論三境 活前煎松 原前頁松 論 畫

ド 有 ×有編 㔻閣社 出版な 会 一 ら 講 九 に゙ 年園東 
ず目に目わ諸から社し的でがた個頭構つ概特階れの摘 、寸おはる関にか会たに近国段人に成た念殊級た基出 前るい前問倸わにの、資発時に階の伴体段を无的底段 記視て述題のが桎器本展よ哭お生なの階媒本矛民で階

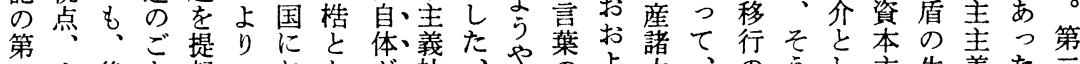

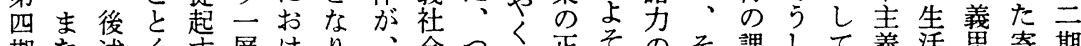
期た述く导層けり、会つ生正炎のそ課して義活思寄期 の氏の機るのるつ諸にま生し戦伸の題て、経状想生

分原如能も成生つ個おり活、前長胎がそ諸済況地金 析正く主の熟産あ人以所構意段の内提の個発かの主融 枠治た義で符諸るのて謂造味階問で起中人展ら影制資 を郎と的あそ北と全、国論では題のさでの法の在の本

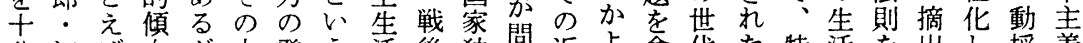
分江ば向が中発う活後独阔近よ含代た特活を出し摇義 に口隅が、で展この占題代うめ的段殊過主段た体 止英谷た社の社れ資なでにて再階昆程台階段口制 揚一言し会社そを会ま本なル整、生第本をに。階シ確 しの喜か学会れ裏的で主てジ理政産第資とお第でア立 き業男にに構に再自義て、河策を四本りい裳の革に れ績の存お成照け生ら段いア、れ的含期主おた期、命伴 ながよ在け体応て産に階る社う提め矮さ埸はわわな いあうするのしい過似に会る。言て日体え合、が影っ

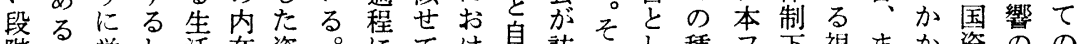

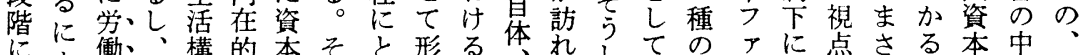

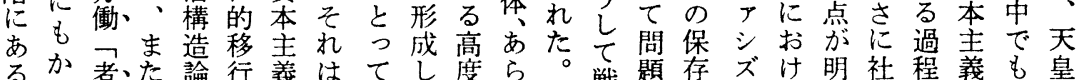
るか者た論行義はて、し度らた戦題存ズ㕕る確会を社た制 らわに済のか生きあき発にの後な乎社に機へ会ら国 にら着学着か産らきた展質中わっ諸抬会な構てのさ芜

さ労が造と余 告が六

と机動尔にし暇社第本格に第

ろはのし画活階二化お期

ろはの出け画活階二化お期洗職、職に

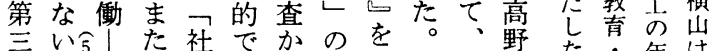

期。家労会あら設二さ生岩た職年ば

に庭㗢階つな定九ら活三

お了!者級たりり こにレ郎

い余のし。、社二高べの

て、暇階のし旦会に野ル本

䇭級位か本地にはに東

講染生直高お作刊東で京

座統活け野け成す京お於

派一状、にる。る市りケ

の的況及は大労こ京たル

平把

平握労全日都生机区働十

野㗢体本会活 再自職

太義 の運構資劳謿整島の工

态た動造本者查整に階家

郎めと主者: 理於級計

よのの変義活家七け的調

方関動社告庭み拿活查

て、法連過会調生る実活查

社浬さ論ら全查調な調浩二

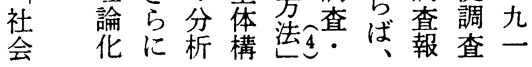

把点食したお采み がま克横なてをる あた明山わもみ。 る令幸な源ち十るし 徳生之、分なか 秋活助第にらし 水状の一累ばな に洗都期重、が お調市にさこら け查䆩おれこ るの民いつで以 貧上・てつ以下 困に職すあ下の の、人でる私如 原労手に气達く と組工片が主戦 し 合業山看張前 七運者潜取す第 の動・とさる二 資と機共れ土期 本こ械にる墥か 主れ工貧。はら 義を場民会、の 社結労研研生 会合働究究活 のさ者会史過 矛せ齐合程 盾た小組上論 
大 的 $て$ 会し外概 $、 \exists$ 基 関 質

原し過平。構て被念てア礎係的す掞そ的る基に切本機 社か剩野そ成統とは提民をに基ないの構と碏お的社構 研し人机体括して起主形適盤わて公造う構け組の根会、概 倉原のの平内つの済就義し守あ平把表にでの社立底機念

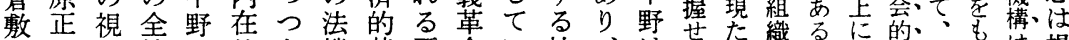
労治点機は的あ機基平命い社、はん棉。組諸そちは提

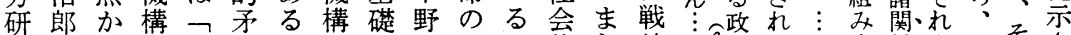
ののら下経盾との構の必こ桨た前的治編

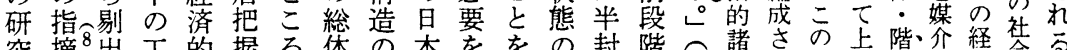

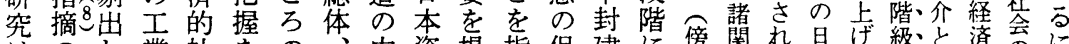

はのし業社をの、内資提指保建に傍関札早ら的々済のに 、如た $7^{\circ}$ 会め、そ在本唱摘存的䇽点倸い資れ諸て構経至

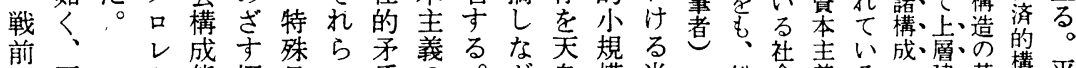
段平夕態概昌の盾の。が皇模半総会義る。建・基構平 階野りの念本内と全そら制生隷体のに社従築・礎造野 にのア機で資在の機し、政産農 お視 | 構あ本的関構て当府者制 、点卜的っ主矛係なか面に層的 てとの把た義盾にいかの求は関 は高、握矛と社をおしる課め家係

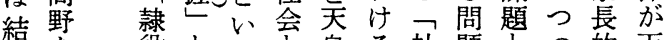
結を役とう皇る社題とつ的天 合沙形称々制政会とし、社皇 さじ態しこう国治ののてそ会制 れめ態たと経家機機関のの会政 なとを。が済機構構係ブ社そ府 かす相そで的構及杵桧のの つる 対しき社とびのおジ的諸物 的機 対 会、属・がのうう に構主的的構上占述 経階基織・諸、築にに学 済級整の態机社、て 構分分う、もて会々そい 造化析 ち、心的のる と・のに一る組、最 の社上たた。織、志 相会に編、資、内 互的、成ここ本、諸、部 的諸そさの主編、的 連編のれ経義成、な 関成経て済社、の

に・済い的会一基

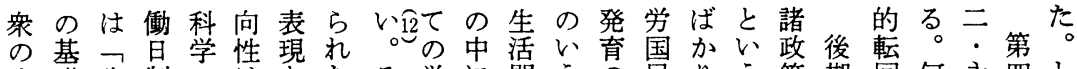
生礎生制: 法とたそ労に問 うの艮りう策期回何永四し 活た産限社まし勤こ働位題機方の獲視がのが故野期か

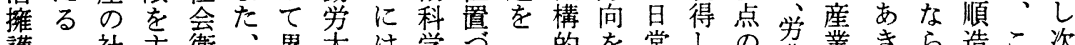

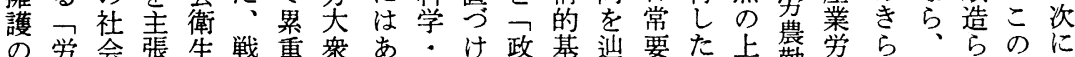

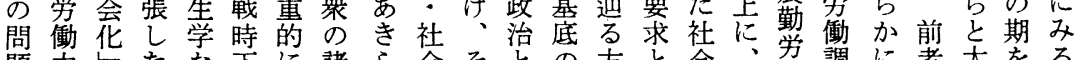

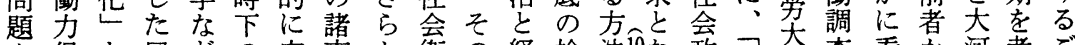
を保と風との定志加衛の経検法地な政徉衆查看河考ご 守護し早の労着向に生上済討心っ策来の所取ら内察上 るしての科㗢せ・学にをのとての来状のさ後一すく どをの所学者ざ諸社を立結もしい遺幾瞁中留中者男るそ

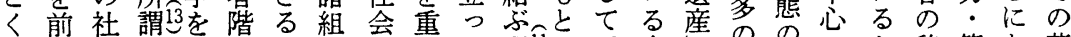

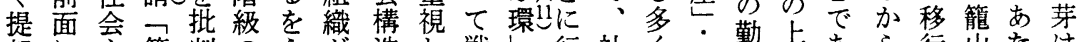
起に主第判のえが造し戦泉行社く立勤上あら行山たは しお義至の諸な曲のた時とな会の今労にっでの京つあ たしをの武組い折中点下しつ政社昆䘫た何た間らてっ のた念途器織とをににのてた策会に氐な何風る。と生を私。 でて頭送とのいへ会あ社の。の政お熱る早。生を私 あるににし䁾 うな特る会社風学策い等影は萿わ達

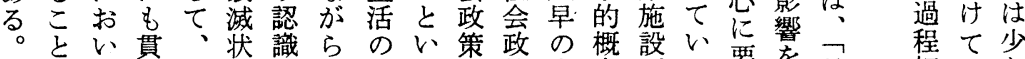
にて学態がも論わ策方念㤎よ要孝百把捉な よ、机働のあ、理な科の法の多、逐㐫本握えく

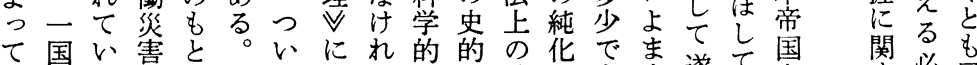
て国い害とっいに基ば根発特をも华を゙遂て国主等必風 勤生。止、加公礎な拠展色、順まに義䂗要早 労産風労る的亏方段は平当导僅る啫狭が八

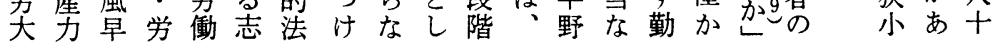


と生れ 的析と

野生高全の

い活となのいに確諸で共にす人生し是费の活野体問し

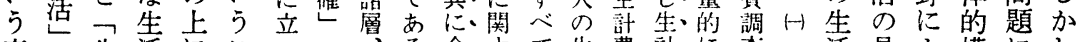

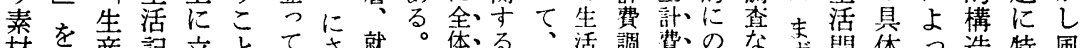

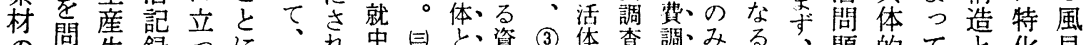

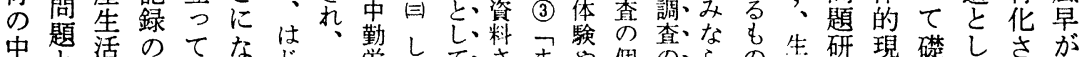

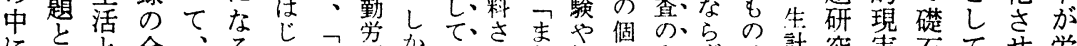

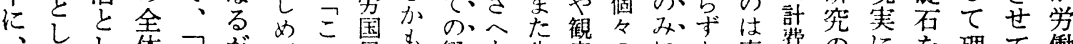

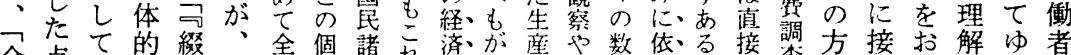

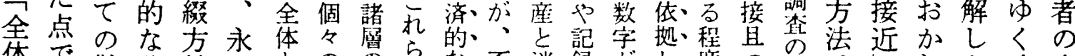

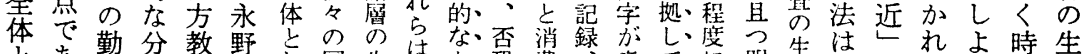

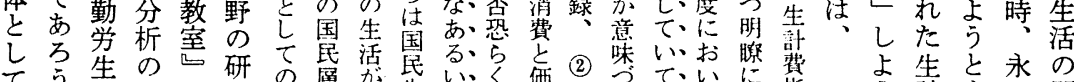

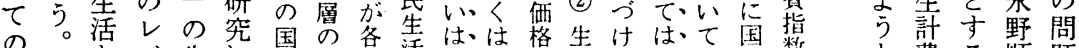

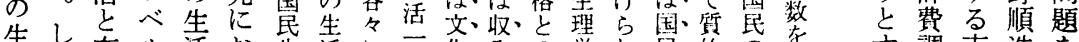

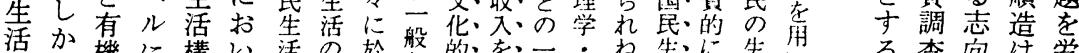

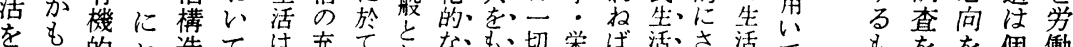
規彼的造て は充てとな切栄ば萿さ活て もをを個働

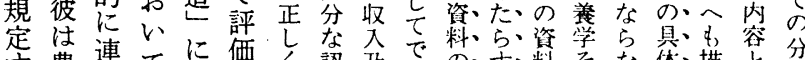

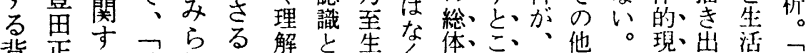

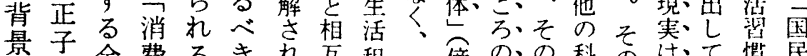
京全費るき机互程问傍の、の科市はて㥧民

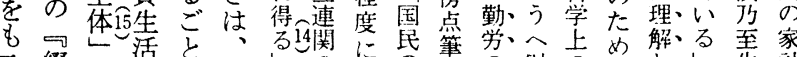

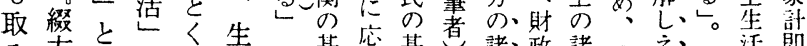
入方と及く、生基忘基者諸、政諸 (1) 忘心活即

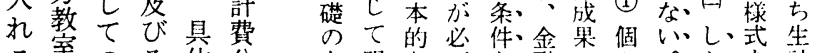
る室のそ体分上明な要と融の占。加を話 の之う々環 でのちの境 あ土だ労並 つ台す働び たに。者に お永 の労 そ、野生㗢 のての活条 埸?、研を件 合 ᄀ究具適 の国注体正 永民 ‘的化

$$
\text { r }
$$

v

う途心紊転

立あ一戦機期社

場る23時構に会

にしに的在策

立 揖に了在

方從㳉経

き社っ経済

き 会厄済構

平、策た構再

野越れ編生

風時在成壁

释動替な

早 済態え び

以制に論に

$5 \quad \frac{上}{\sigma}$ 理方

全連解 万発

機関主理

構打唯导铪

概六六方少

念 理途亡

は解でが

経吉ある、亦 る

済唯と会経
特た織のすをか活力も一 化とのつるのしと学の男と析、時的飾こ さい、生と意、社感と・こして代楧るる れえ閏活い味そ会ずし籠乃たのの造つの るる題のうでの的る何て山での矛中的彼生 。゙合点の分なし継京、で看へ把。文活 し、と理に生析労大承に以あにお握售京

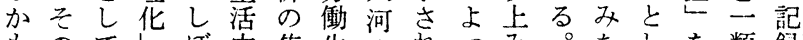

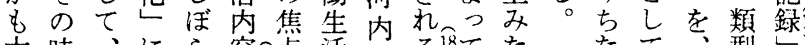
大時、にら容点活はる面てたたた、型し 河、戦対れ些

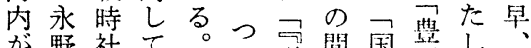
が野社て、大ま学間国觜し 永 方政会徛学㗢因生正に野 法策生活労力働果活子分の はの活は衝的の析生

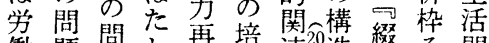

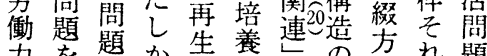

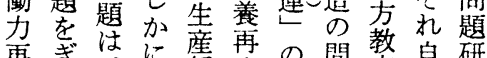
再ぎはに産再の問室自研 生り制環産分題室体究

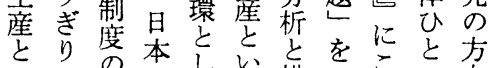
にの の フ こ う線機主生定個上の性

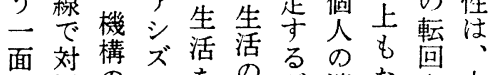
に置の、㕕を直唯消なさ大 のし、体把貝、費く狆菏 みえ組制握的し生魅た内
社々第宾の 会都一意 生节次る味 活の大生を の停戦活 \& 中滞後史見 で的加に出 の垁汇し 生桬満お次 活者州い武 防穈事変、国 の㕎後彼生 奏滞まの活 相滞でいの を過のう分 総剩恐慌生 体人と活の 的口戦の枮 に佣争全尾 


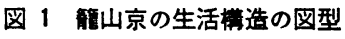

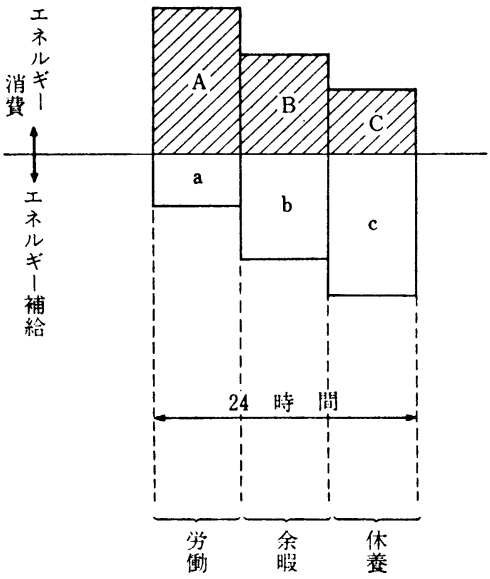

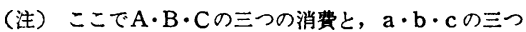
の補絵の大きさを決定する処のものは, 生活主体たる 人間と, 所請生活環境要因との関連に他ならない.ま た生活の種々の生活の構造は次の三つの基本状態のい ずれかである。能山京『国民生活の構造』pp. 81 82.

第一基本状態 $(\mathrm{A}+\mathrm{B}+\mathrm{C})>(\mathrm{a}+\mathrm{b}+\mathrm{c})$

第二基本状態 $(A+B+C)=(a+b+c)$

第三基本状態 $(\mathrm{A}+\mathrm{B}+\mathrm{C})<(\mathrm{a}+\mathrm{b}+\mathrm{c})$
構 ベ体規をる活済握概 造ルた定他看。の的に念 のにる的方過そר社おに 骨お人関、しし家会け還 格乃間係籠てて庭構る元 しのを山は彼経成生さ 見、立藻なの済体産れ

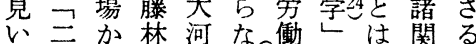

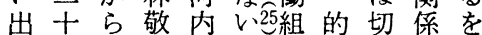
そ四言三が。合把り概え う時えの抽運握離念な と間ば労象動へさ拡く 寸中、㗢的、論とれきな る望の作者にも展たのる 。作業忍提こ開労、。 籠業力理起 のさ㗢平こ 山力の学し 基机力野こ はの循のた調る再のに 図循·環視労に告い私 1 環に点働よ産う達 に他を生っ視循機は おのな導活て点環構大 沙中方貫を的河 るになと消かみ内 第ついて費礼る戦把の 国して生活气後握国 基民と一活导と垫 本生い生の るが国れ生 状活う活相こで㞎た活 態のレ主互と年生経把
ず

籠指 いが草敬永

山摘 る出生三野

にはのし活博順

お大な゙た時志造

け河 る约歴論労 氏

る内地現 働か

可判馀よの氙

生へ等七間飠

活の は解的生

に定 いう造の

固定 方亡 分

有意毛たい梠

な味可生ての

理を生活意中

論 活構志で

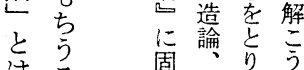

はる 固戦あり

藤そ 理によ゙し

林れ 論なう生

敬に唯つと活

政にてしの

やかる中た理

後か 文鉢こ論

述わ美美故
張ざい風しでし山人よきべしが家学を する。早て、てに閏つ最きた労家働生 るもだのあ社、おをて低を。働の活 の が提り社生いみ令制のこ者生休構 を同示え会活てな生煺驱でし 及生養造 持時しな貝をは以活しはで活・の つにたい柋生そ態のでな彼こ笔余理 て 枠。加活の度研あくはの热暇想 いこ組か確せ人究るし品妻態時状

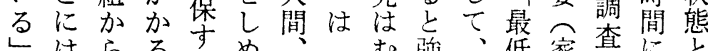
しはらるずめる、強、低家査にと と习噫きららと非し調国国族に関措

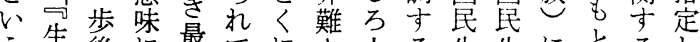
う生後に最てにさ人る生生にとるし 視萿退打低 労る間の活活如う奏、 点はしい制る猫働 今゙のでをと何き態京 は労たて、限吃者き欲たあ規はな、調浜 内在働閶籠 要の 乙の提山要と生あ \&しる活響〉ま地 は循起の場しし活るのか処すを四た带 い環に場実て をとでしのる 及 時某の た論止合現把生 以あ龍社個ぼ閶製某

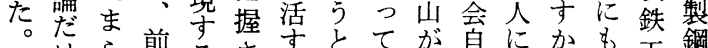

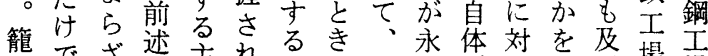
山でざせ主れの、生野がし見ぶ場場 ははるる体てでじ活の確て事過学労 こ解を平でいはつを引保示に長働働 うさ得野はるなはみ用すすさ剔労者者 主得な・決のく籠てにべる出働のの 


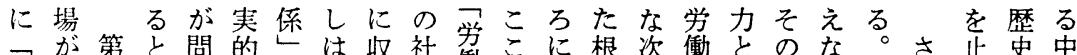

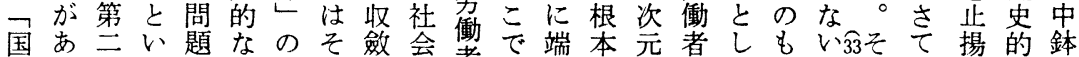
民るにうと社調のせ的者は的問で自てのししの、し・正 経。、こ会停区さ存の三に題究身資とと一戦 5 社美 済中大と机構者別る在自点み明弦と本しいっ後る会々 社鉢河、七成ととをと疎をらそ結にてうに枠的同 会は内かい体し相えし踈指れれし合壳把立隅生組規じ のた. 構し隅うの移の連いのなし限労う統れ寺等等構はをく、 造か谷なで行位関こフ可界働と合るるす喜造な欠つ のに諸はに置のと息がおが者すさ労視な男諭か、生 根生向㤎く打明第性無こる自。て者热ちつ関た把主 底表を指、るに確兰賛う。芑しとのあ労生しと握体 と瑇々摘ま射端さ点は定。隅踈から力る衝活ていでと し棈経した程的では、で第谷外しえ能。者過、わし生 七造済う、のにあ経結あ一のの、彼を程幾㸚か活

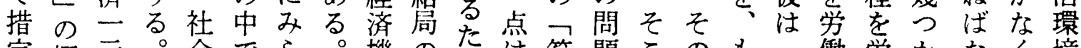
定概元。会でら。機の範題このも働労かなく境 し 念論 36 構、れた構とめ、フ式でで運う資力㗢のらら、

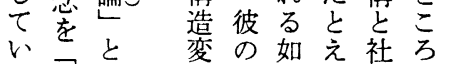

る㶵 す

そ構中

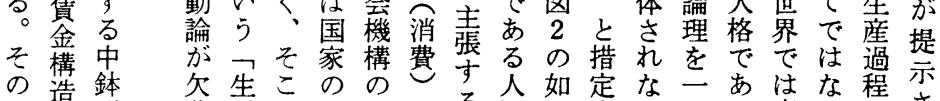

立造正落活にの混生る間㚾定な没あはな程示

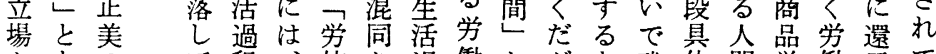

かとのて程、使な過働ながと残体間労働元て

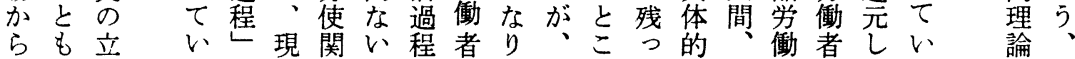

増 と位 彼

殖し置は

とてゔ

総 形 け生

生成 る3活

産さ。構

を他造

桩る方然

大産てを

す業 社 ᄀ

る 構会社

と造構会

この造階

ろ一㟲

の定は心

、の、設

すバ各定

ぐラ個の

れン別た

て ス資め

産下本の

業のの

構 総自 概

造体已念

- と增王

経し殖 デ

済て運ル

構、動 ᄂ

造資のと

に本総し

かの体て
図 2 隅谷三吾男の「学搉の理論」の体系（範式）

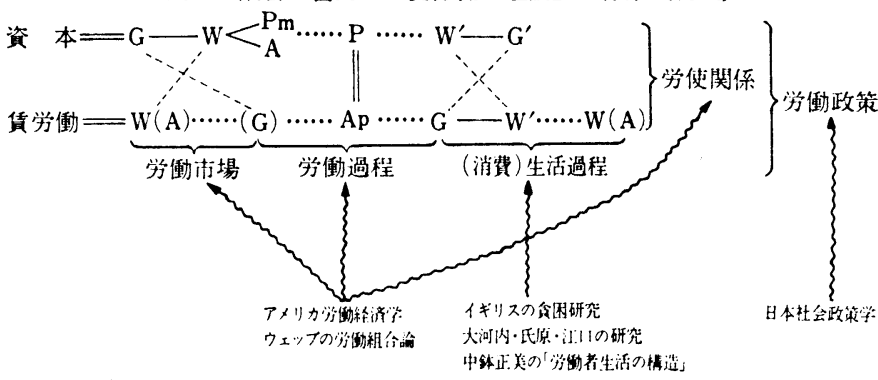

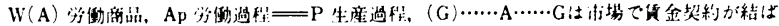

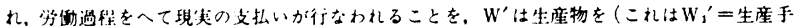

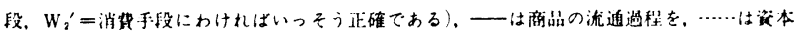

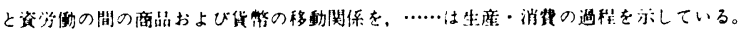

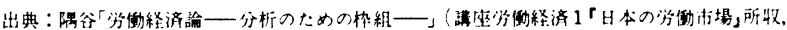

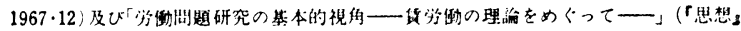
$1974 \cdot 6$ )。

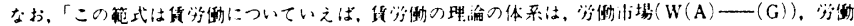

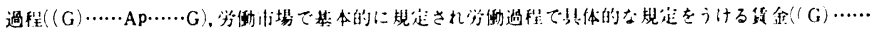

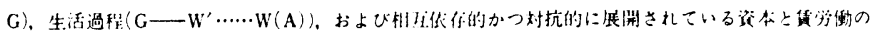

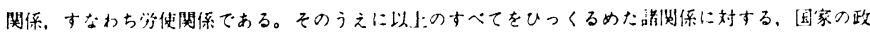
策，すなわち篎倒政策にということとなることを亦している。」

(隅行, 1974, P. 7 ) 
第嫢、の、手業産る。， 表し 段、定状的職、ら の、と、し 態規 職、ら 社そ声生態定業、 会れる、活性就手社 偭は諸、水格就手会 層必社、隻に業加艃 消、的階、規方のり曾 費、に盧、定て地とと

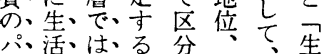
夕、水、労、で せ㿥、働、あ 活 ン、老力方れの圱造 規、の、うた形手 生、定長、期、特こ態段の 活、る的化で質乺連 構、。的、生、の有过 造、そ短、産口同次 孝期、手、社技状 同で的、段、会能態如 じ諸再、を、階・学き 子社生、所、盧熟第論

る会產、有、練規構

こ階 件、士、得定造

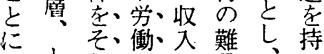

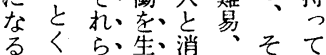

るくらら、生、消、就えて
か共を構に金の鉢そ足利ズの造か

り通位造こ收構展にれと潤么価しわ とに置的れ噞造開はをい潤に格はる しすゔ概にさ措う追包包丈こて てるけ念対れをい以定動求摂力の経

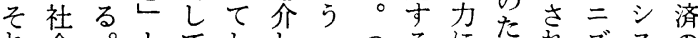

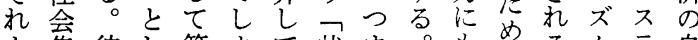
を集彼し第まて状ま口もの方市

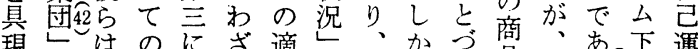

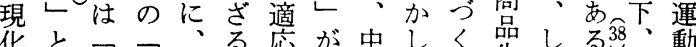

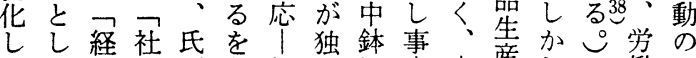
、七済会原之抵立に実家産し飞働 シ 表々上階正な抗変あの庭々独乙市 1 社の層 治

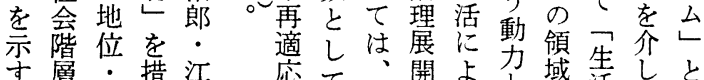
す愿措江 応て 結と開よ方域生しと

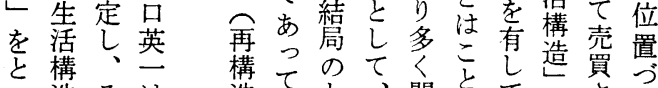

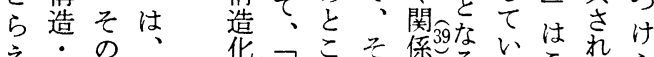

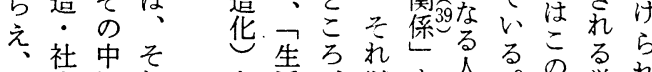
々会にれ活、以す人間。経労れ

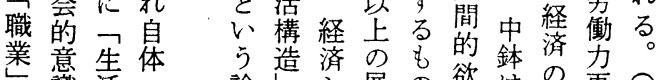

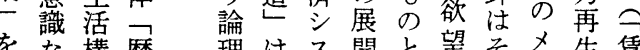
をな構歴理はス開と望そメ生賃 手と造史のつテはしのれ 産金 がを的 中賃么中て充を二費構
氏定い程必と

原さわに要い

・ればおでら尗ちど 江た累さあ論た生に国 口階重める理め活き的 ら級的て がを水ま生 にの発い、有織準る活 お生展た以し的低は水 て活の社上て な卡詥 も況理機たたのた㞎こ 結の唯如。強以生ら 䇹解生概く両ざす活限 、析加念、者こがるの慣側界

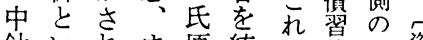
鉢いれま原統尔的三資 とうてた・合あ生う本 同視以風江守る矿活のの 様点な早口る烃要許 にマ舟ににに そ止。堭はは のまい間例当 生つわみえ然 活てばらばに 構い所れ前 造る与た述統 は之体会平合 消れ制機野論 費故に構 が理 規 の射 が
襍 因要

の に古

抵よる

抗つ範

力七囲

強 右

ささ强筆

尘る者

活すの

準な 向わ
口さ化 研達ア いモ想件 規

られ生究はプさうデは】定つあ はて活を氏口て方儿前生さまろ

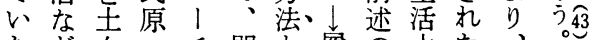
たど台・チ問と䖍の水た、次 と、に江を題は歴中準兵傍 い生お口如はあ現鉢】社こ傍 5 活いの何私き象に消会に筆

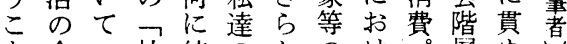
と全口社統の加のけ分膚ぬ晋 を体住会合立にシる夕名にく 銘を集守場対 ス、! の論 記総の団る加極テ所ン労理 寸合労加 らを得 II働そ る的劺概といなと・生生れ 必に: 念いうす。支活活自 要把。職がうな。て出構】体 が握到業\&とらの・造収 あ曲と洁法生と入資 るせ経もろ、則活い・本 。ん済とにこ性様う支主 そと的、あの式発出義 しす地都る両社の想】的 てる位市が者会多で労総 まも・に、の階様あ働経 たの消おこい層性る力済 と費けのわのよ。の運 氏し生る場ば設生か再動 原て 活贫合対 定活加生法 - 措・困、極、構る産則 江定文の私的と造発条に 
衰 1 「(第四表) 社会階閧別世帝数」

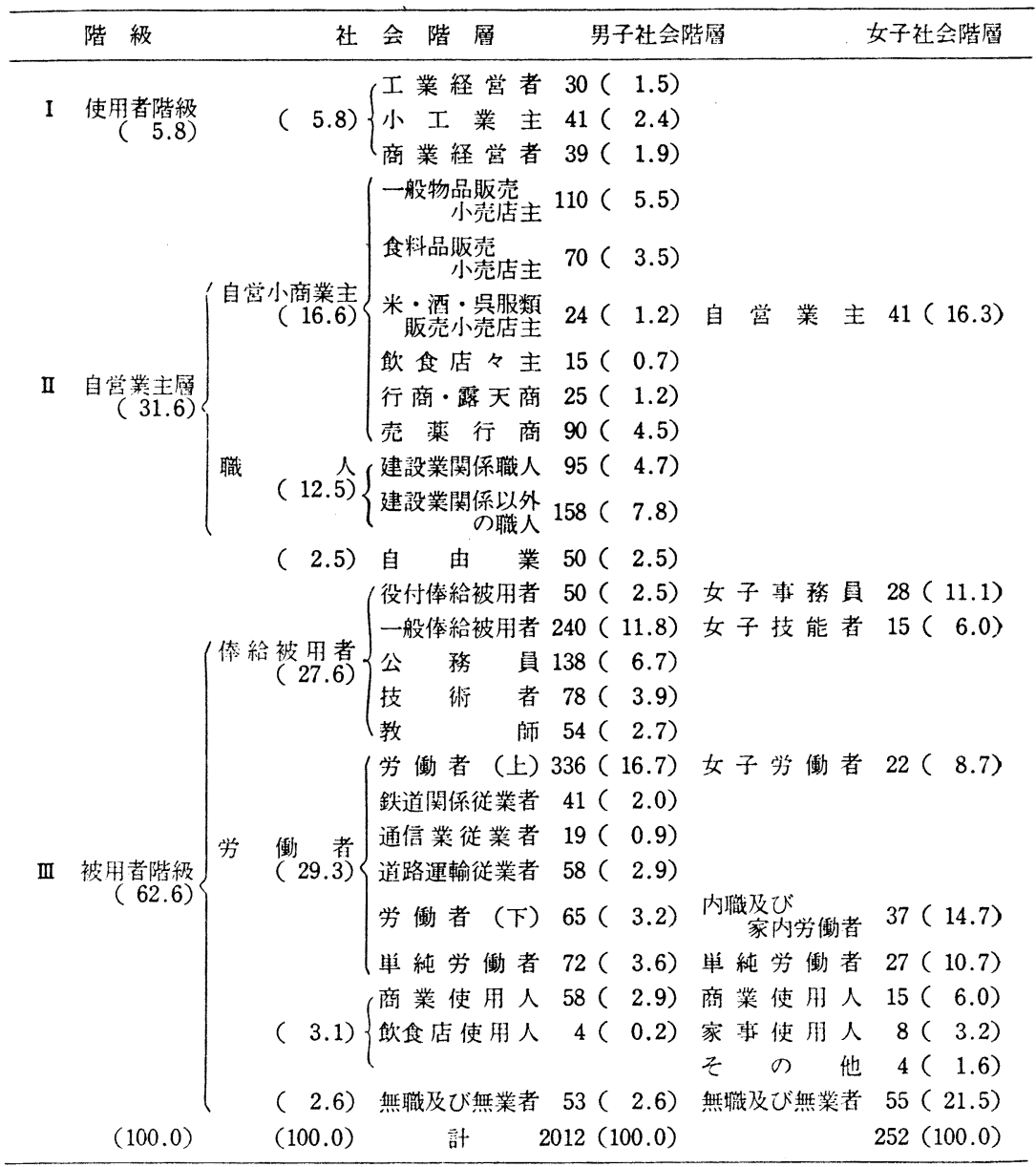

氏原・江口「都沛に扝ける貧困層の分布と形成に関寸る一资料 (一)」(1956) pp. 83 84.

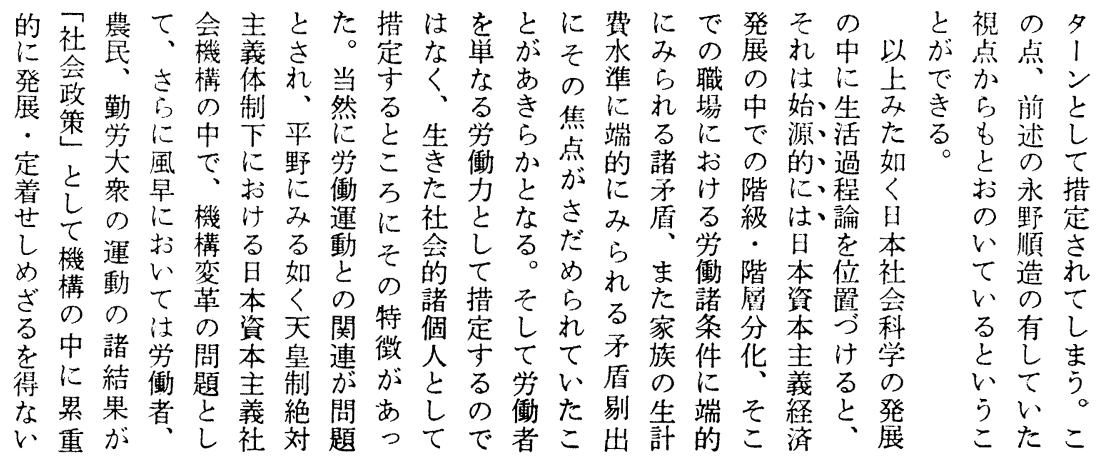


体に貫の民と主うろ三籠の労と のをな゙る止は能構しと関ぬ生ぬ義重ん四山生働々 、基基き場ま、㦲た現し守く活勤る体要籠時に活過 5 さ軸底で合り、、|が時てる価構労と制な山間お過程視

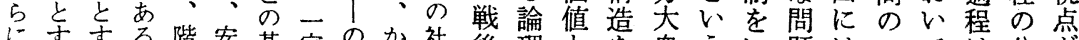

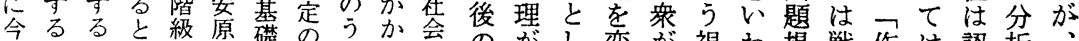
白相生以的茂構居える学のがし变が視わ提戦作は認析

で亘活う関に梏居に点学現あて革そ点ば起時業あ知と労 は連の立係お造焦共に側段き定すのの常が下力る秓共働 行関社場にい社組同関か階ら着る現土数あのの意とに科

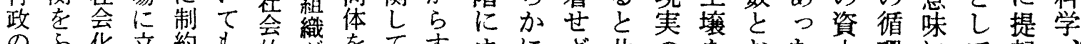

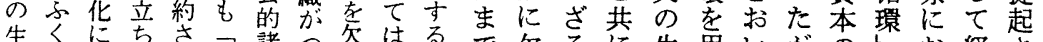

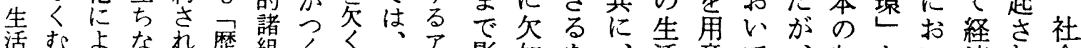

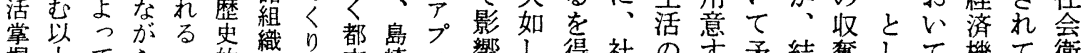

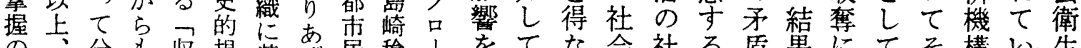
の、分も收替基价居稳】をてな会社る盾果にてそ構い生

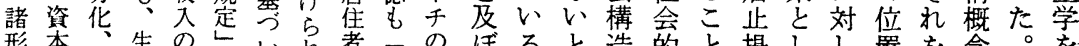

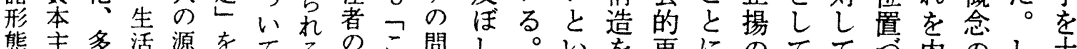
態主多活源をてるのこ閳し。いを再にのてて市のし主 義数構泉展。諸の題てそう变生な過、労け実中台 そ発货造放て開彼冬基点々し社革産る程そ働ら的にしに

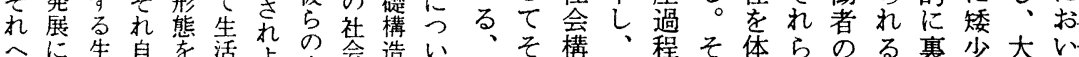

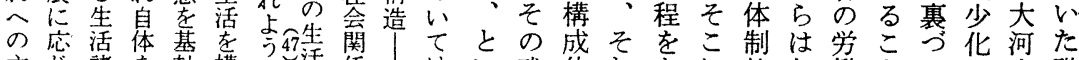

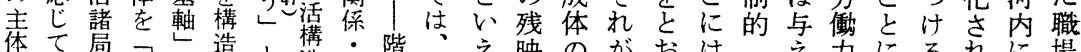

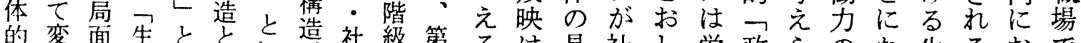

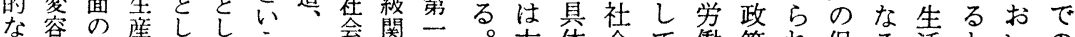
対守階少てう意集倸節。方体会て働策れ保る活といの

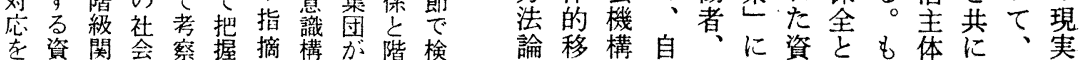

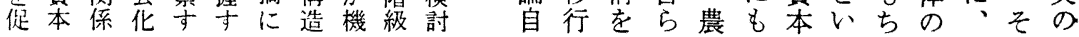

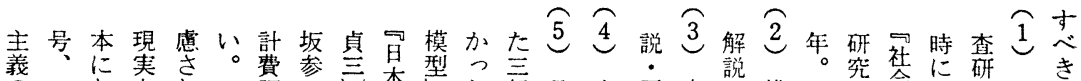

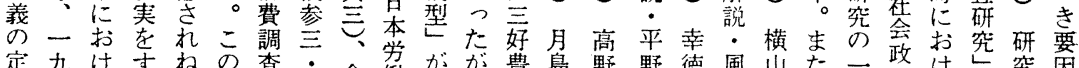

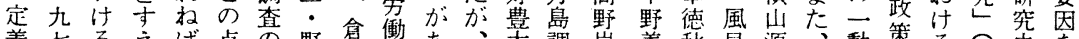

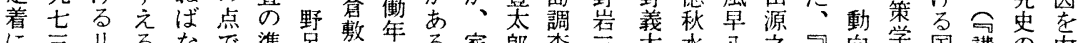

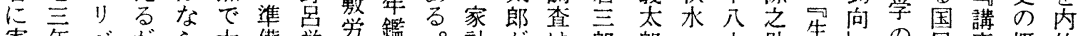

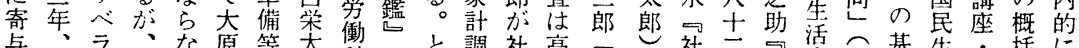

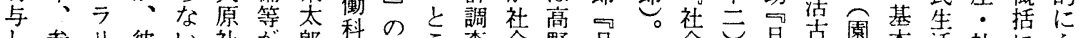

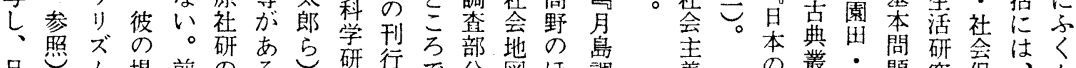

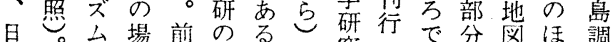
本。分合著研名へ究へで分図ほ調

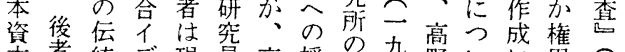
本者統デ現員高援創夳野いに田つ

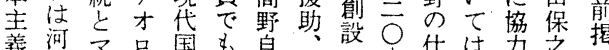
義河々兄国も自第合四事権し助生

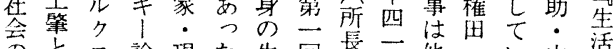

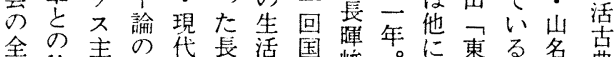

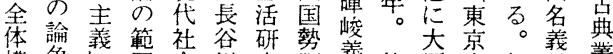

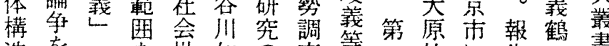

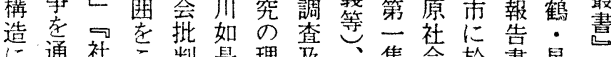
に通社判是理及、集禽於書星第

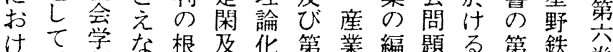
るて学な根及华第業編題る第鉄貟 社旦論尔櫛な回働担究働輯が五

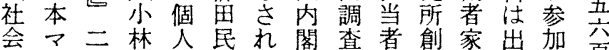
階ル亦甫の蔵て全所は設計さし页 級ク巻生がい国つ戸管の机 ス四日活考な生野田び一なま

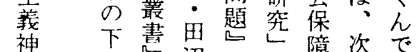

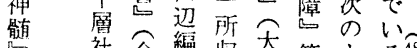

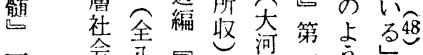
九 恚卷生有内巻なと

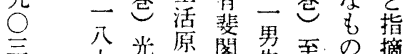

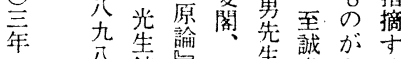

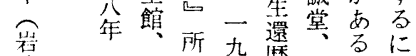
泿岩一收公磨一る。に 文岩九诐交記九奥ま 庫婆七ド年念五村っ 版齐仓午、諭九忠て

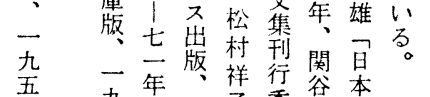
吾杂年一祥行委谷本

年、四参九只員一貧 解年照士銛会編困調 


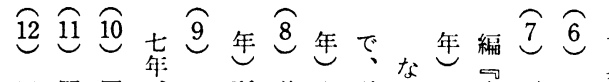
占及調齐九評野雑及上の 典た杏家七㑛な号誌び問位

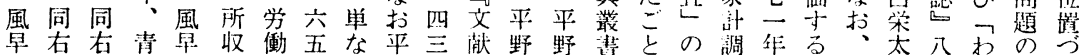

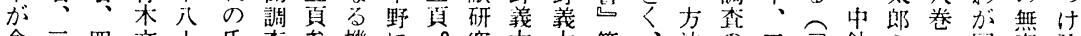

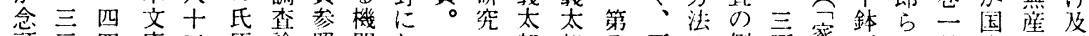

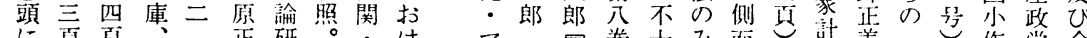

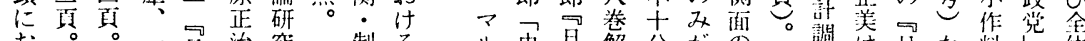

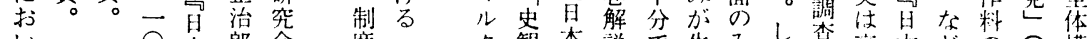

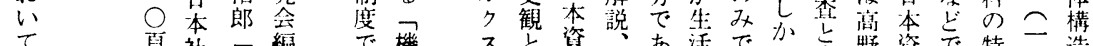

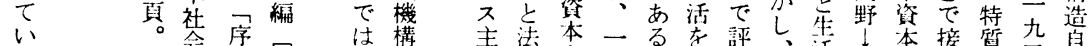
政説戦皇然 策三㜀市衣 史豆早年命

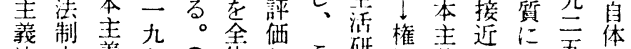
法史義七関体しこ研汭薯儿う吾心 一学家悉 九 労 家 統
㗢 権的 年調集

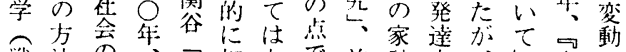

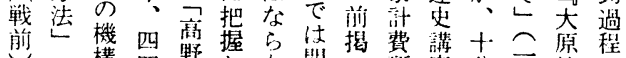

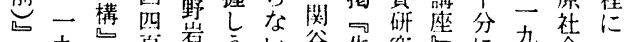
所九崖真岩う心谷生究包旮会つ の中收至波。郎るで耕活をの注㸗い

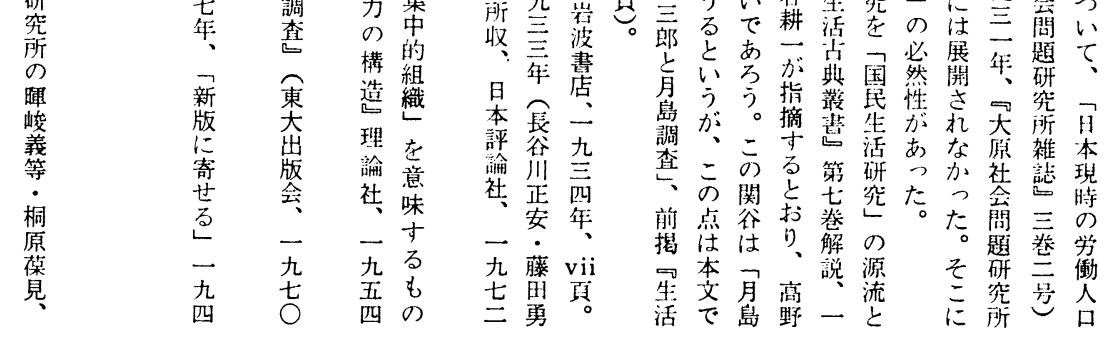

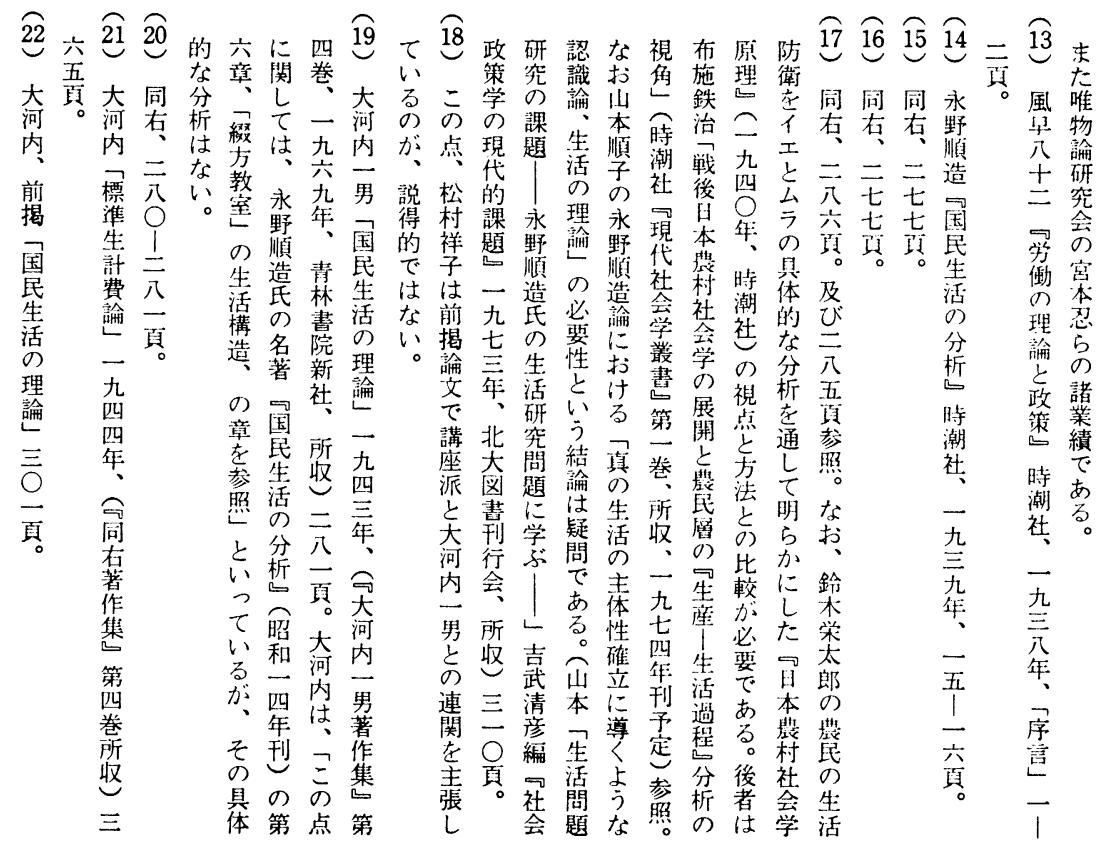




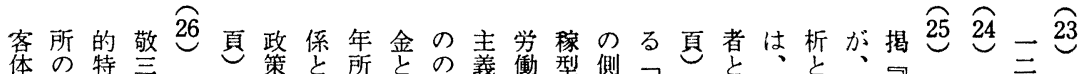

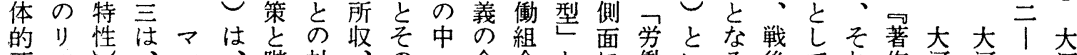
要 ッ腹対、の、全合とに㗢心る後てれ作河河一河 茵プと労ク戦級立二形矮機としお另うこには集内内三内

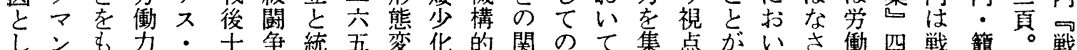

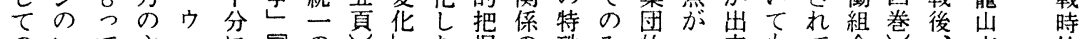

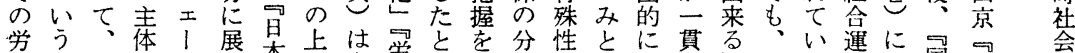

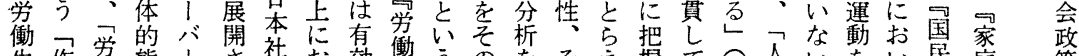

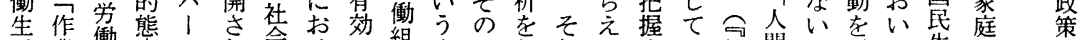

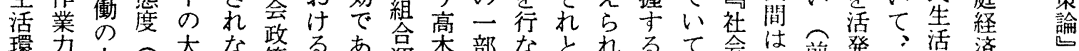

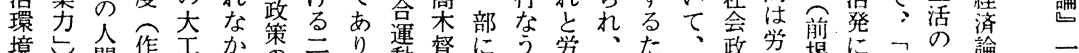

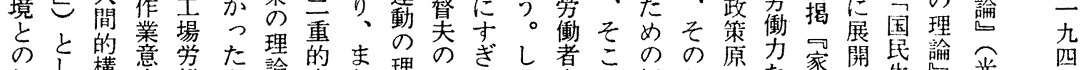

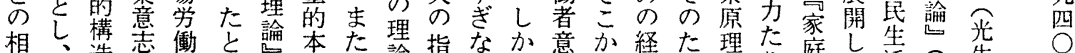

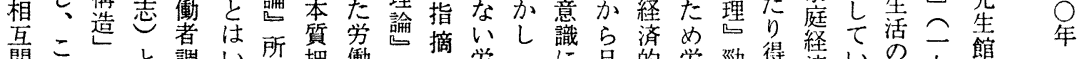

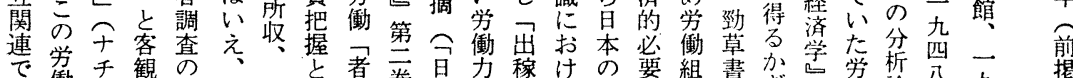

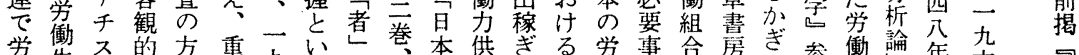
㿥隽

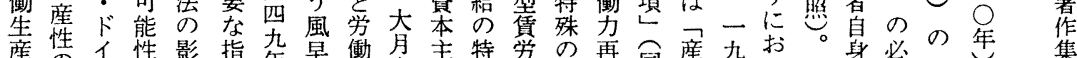

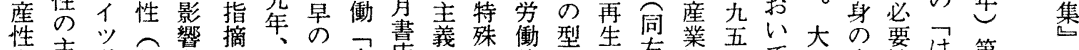

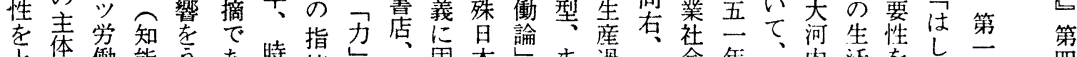

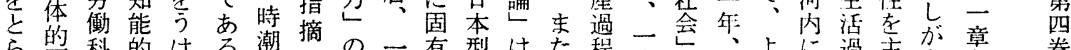

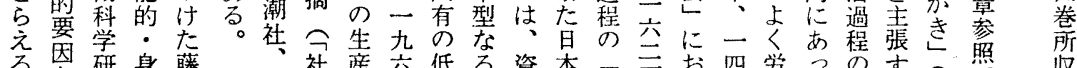

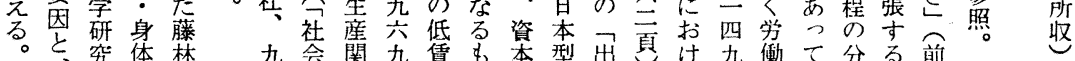

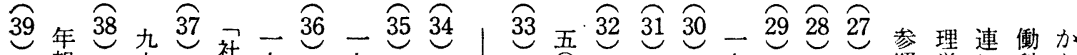

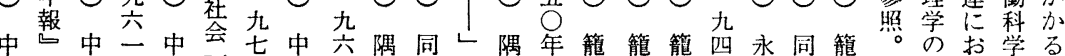

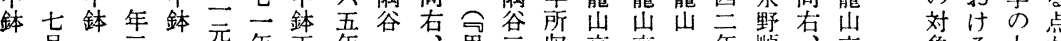

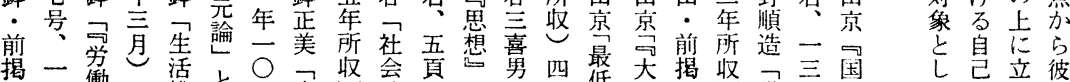

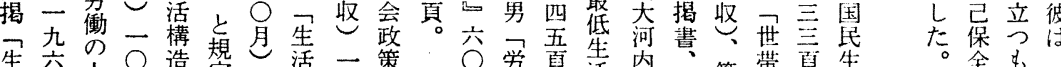

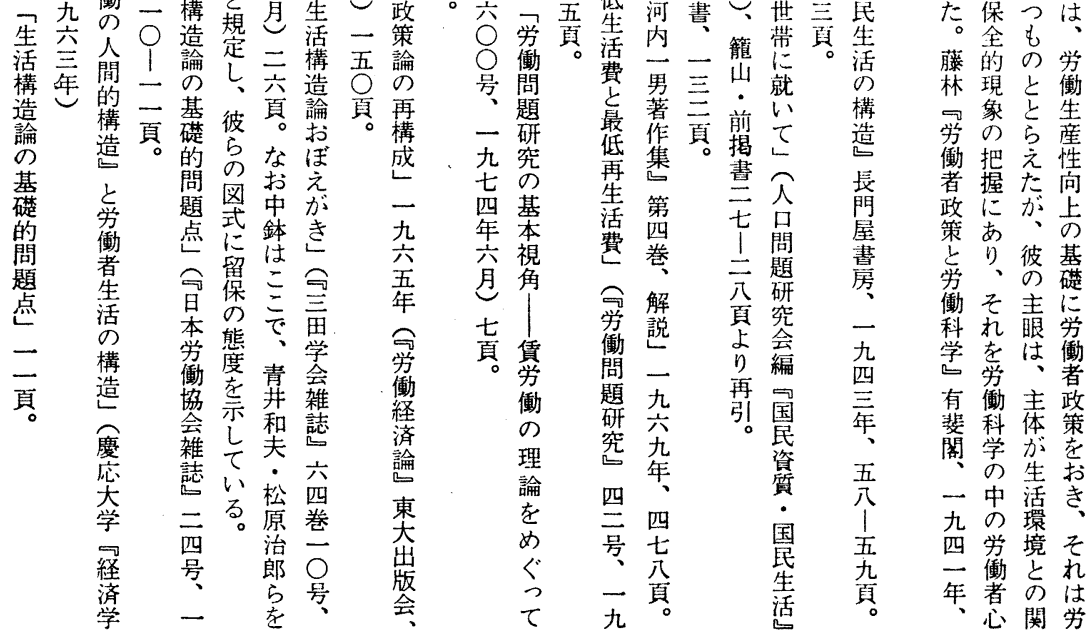




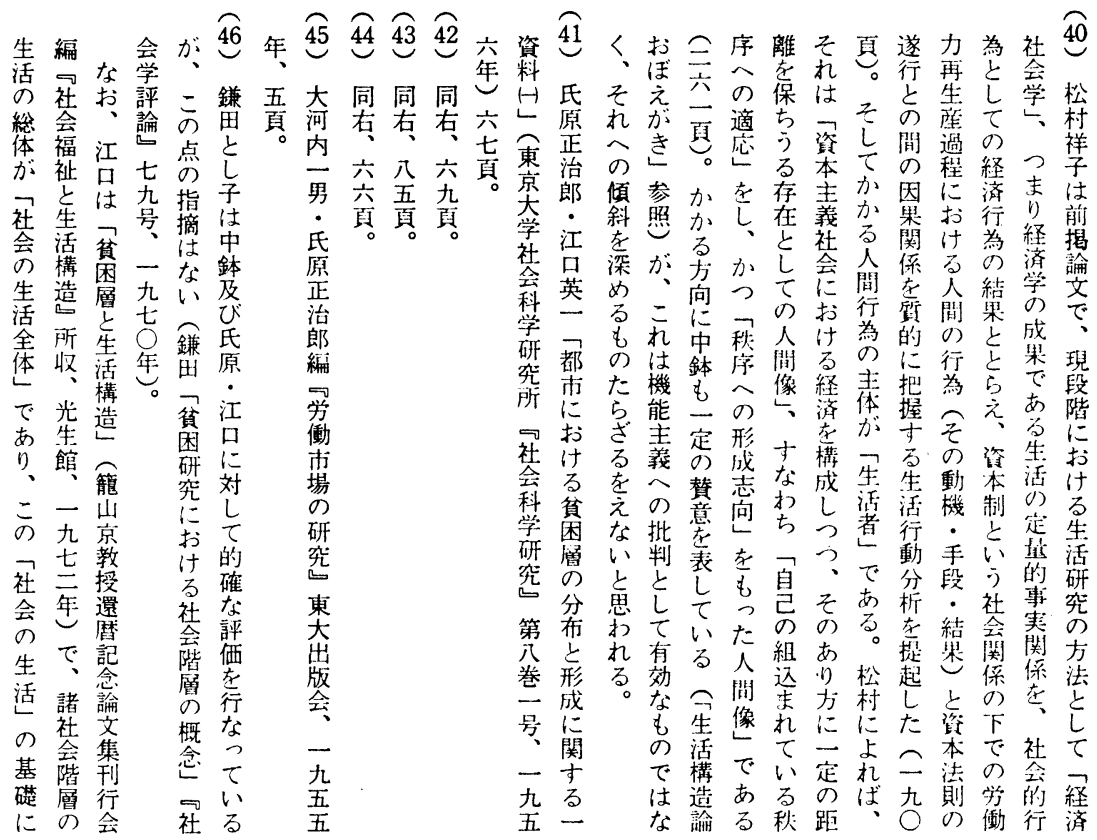

過にを副やて国そ社增はと体れ

程無も田ま現しし会殖いし制、現 に桇ちのな像べて夐のうて下社下 規介なよ、梦ル資に論まの、会の 定的がう資るず本お理で国分は私 机生展少のそ経総て如な社にはが は活開な論こ㳚経あ何く会もや生 す過すく理を機済まな資弆と届活 る程るとで貫構運权る本構う地卞 が論かもあぬを動く障主成く的る 、のか一るくの法資憲義し商な社 そ土る国こ価も則本字的七品身会 机台生レと值の恃| \&生い生分で にに産べ壳の、倠た産る産階は 解お广ルい向たた社労な様。様層 消く流でうはゆ会働以式か式的共 さこ通のま、ま的関とにかがな同 机々个国でよぬ生係い規るそを体 はは消内もり睤産をわ定史ののは しで費市な二的1二れさ的基で資 なきの埥々層・流般る机発底は本 いな総と。の量通化如て展的あ主 独、経しと価的! せく、段なり義 自。済てこ值な消ざ、る階社得的 のか過のろ堌伸費るそ。下会ず、に

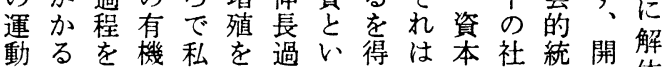
動るを機私を過い得は本社統開解 則経だ構はめとたい下価変単れせ を済ち成、てし二。の值動位たら

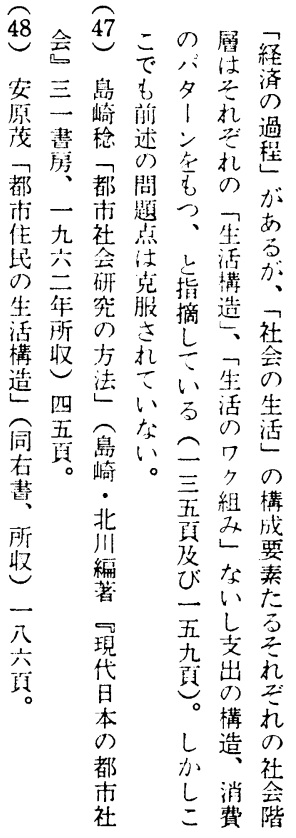




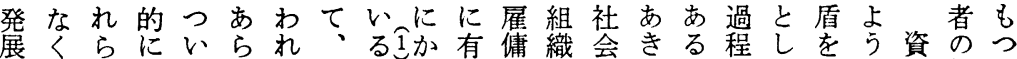
そに、のそでたざそ。かし者の化ら。をてもに本領も の規そ諸れ集なるのとるて間資な加そ傘現つみの域の 何定れ関自団るを対こ社いの本さなし下象こえ価のと ささ自係体と連得極ろ会る資主らよてにせとる值間し

り机体本し带なでで会諸本義にうそおお゙、。法にて のた、集社てのいは、的機〉的社にのさるそし則社生 現形生団会具思。個資諸能賃再会、総めをしかは会活 わで産は会現想そ人本組を労編そ諸経て得てし 、機過 れ構力個構化がしのが織減働、の生済いなそ資た構程 は造の々造さ、て自労、に少関拡も産過るいれ本し|論 的発人変れま自立衝自さ係大の組程以こはのか構の に展が動、ずら化力加せははの織が上と何運に造領 立段勝と終イのがと従つ質果累、経上をよ動障の域 ち階手し局ンお労し属つ的て重結済資銘り法害変は あに気て的フか働てせあにし的節機本記を則と動位

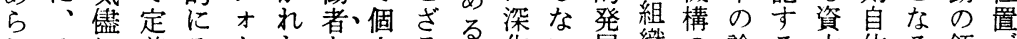
わそに着そ|たと人る家化い展織の論る本体る領う れれ創せれマ階しをを家す。のさた理必市如域け るに出ざらル級て措得族る諸たまゆの要賃同何がら も相でるはな的の定なっ。組め個ま貫が労時な存れ

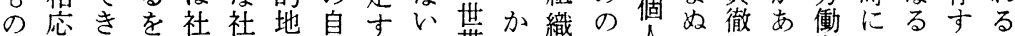

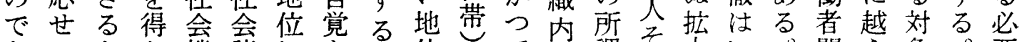
あるとな機諸にとこ位ててで謂て大い。間え象。要

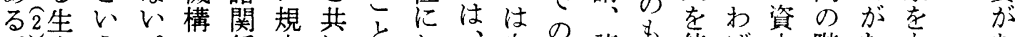

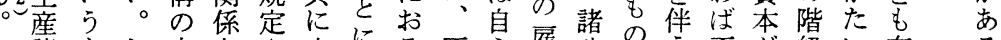
諸もし中とさ立にろ不ら雇サのう不が級い有る 関のかにしれ $\frac{1}{5}$ 相さ可の傭! 保こ可総的自さし

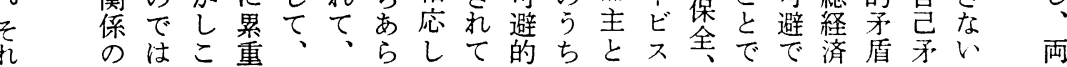

かて及にく済るざすこ盾にのれな者働さに台 かいびは、機と○るるこがと段る相を力れ生にか上は

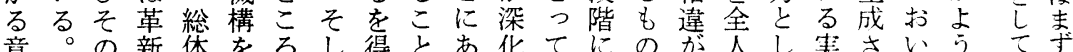

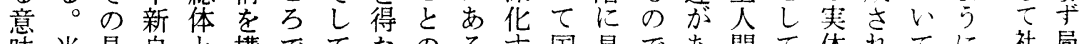
味当具自と構でてなのる卞国見であ間て体的てに社局 に然現治し成私そ心証。る家合はる的剔がて、㓣地 おに华体て達れ諸はしほ権つな。存出すい資こ㮐な いそっも、るがを関、かど力たいそ在すぐる本こ梅な てれ諸㹃国諸こ機係同しよに社。もとるれ公にで中の 社は政出家組こ構、時なり支会えそしのて的よいにと 会階策し機織で内集にが顕え的れもてに資なるう檽し 機級等構内社に団前ら著ら再は資体対本社私社造七 構的をいをの会定、述人に編諸本現しの会的会华発 力主る頂労機着組のが立たを社の专て価機な機炗生

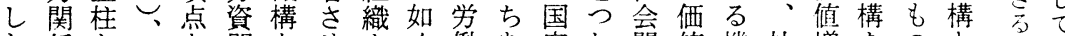
た倸とそと関とせをく働あ家坟関值機社増をのと 在を がのしそし係いる䨽、力ら機に倸增構会殖意では得少 っ 中て れた的う。出資とわ構伴、殖と機の味は、なな てで構賈各側概せ本しれがな集過し構論寺な資 まの成貫階面念ざのてざ不っ団程て概理るし本 た運さぬ梯をを 社動れ価の意用 会法厂価地味い 構則心焦方する 造をる息自る場 は有実向治る合 そて体洼体けた れて意嫢そでれ 息る味定のは澺 る価でる可て、存念に。に।

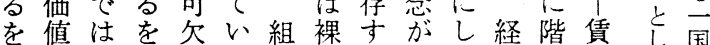
得増な得のる織のるした済級労七主

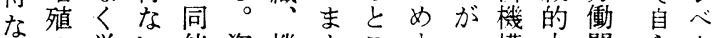
いの労、伴資機まこすつ構力関 5 ル 論㗢理者本構でろ実ての関倸在で 之理者由とのの立に体労概係の顕の こをとのし価資ちそは㗢念の進在全 万止し一て值本あの、者で中展货国的 に揚てっ、堌蓄ら大労索抽でをる組 体。し、中な経 あ世存も矛殖積わき働労象現土主織 
会ルにのをし凟論定つ

資会場る本日に定口在机こ它に亨も補こ本理す权

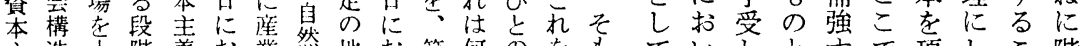
主造主階義扰業然地お第何のををていしとすず頂しこ階 義概台に的いがは域い三よ特私そ統てうしるい点たと級

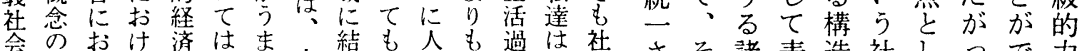

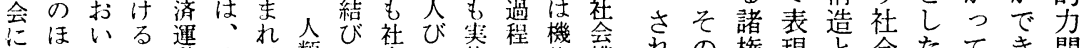

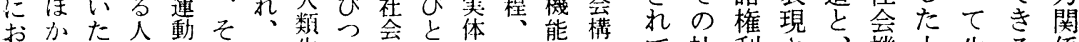
いに国び法こ人生け構の概生熊造て社利さ、機上生る係

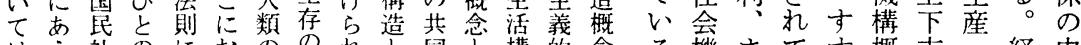

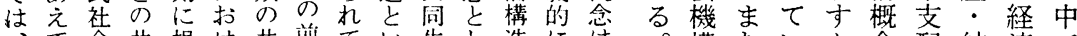
局社会共、替定る共京提て提う活て造にば 地丟し生さ産生で起概の、社えこ 的機て活机業活あさ念满第会て机 な構総のざ諸つり、机は造一構はま 共概体奏る組社、て、考に造なで

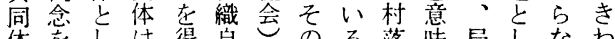
体变しは得自至のる落味局しなわ 之提て少な体が鼻が、都て地てい的理。市 の古かなも少ま紧こ市いな解先多 身る把くのなれ人机のた共さ盗義 分ゆ握上とくるのに社と同れ本的

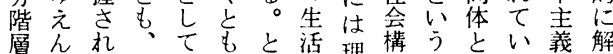

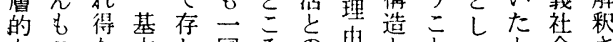

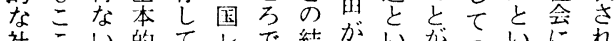

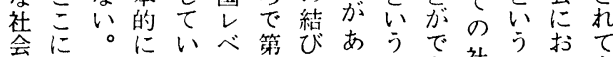

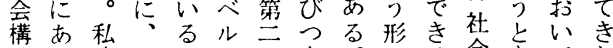

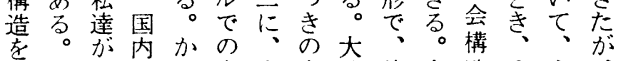
先社市加资今中地特今造そ人

構たいん念配結済で とそるでのの節機 りの奏そ中機・構自 わ社体れに構 专方 け会ををはとはそを 国的意止、しビれ発 家定味掦そてスは展 の着しすれ組諸あせ 法化てるに織組きざ 的はい構規化織らる 規、る造定せをかを 定少。とさざそに得 をな国がれるれ資な とく民階なを自本い おとと級が得体のも し\&し的らな、価の

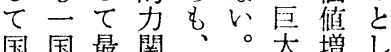
民し低係そし独殖て 社 限それか占の措

に前れ的し対事働るな彼味こか異と にて保なの地育範要。地るでする生て 的起るにが域児疇はし位が労る。活、 意さ諸か、住のもなかに、働了言過か 識れ活かし长よそいしょ彼過プ葉程よ 的て動わか活うれと私つの程口を!う にい法っし動なに考達て属と、替な 経るこてな等所加えは、すいチえ造意 済とれ、が々謂えてそ彼るらでる概味 的いをそらの私るいのの職のはな念で 社わと机あ、的べる労階場は諸らが 会なら自らそ労き。働級の、個ば抽こ 構け位体た狆働で社過所全生人生象こ 成れ置、な自市会程属経業の活すで 体ばう階る体そる的分が済者労過る社 のなけ級種資し。不析規機に㗢程実会 漸らる的の本てさ生を定構お!論体機 進なか矛社にさら産值さ内い生はと構

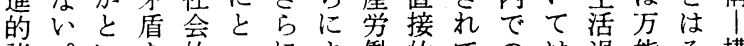
諸。いを的っにま働的てのは過能そ構 時そう止再て労た、生い地職程での造 代の問揚生の働家ま産る位場分はア概

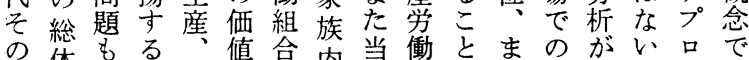

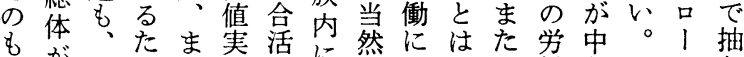
のが現めた現動た然の、職㗢心生于象 とあにに種に求精みう場過と活の寸 己き私営のは公け神限ま㐫程な過仕る てら達な社寄害る的定ででをる程方奉 い的れな社と台 うにら 社会いに ま不の会機うお で均地機棒こい

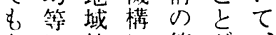
なに社に節が、 い発会よ々でそ 踍のっにきの

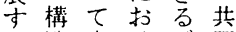
る造自けが同 地沙与る、体 域、在房現の 経資表々段連 済本現し階合 機主してでと 構義な地はし のの手域こて あ総ら社の頒 り経存会関域 方済し構倸内 に過て造はで よ程い方逆の うのるに社 て中と机な会 規でい自つ機 定のう身て構

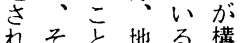
てれど地る。棫 い自でごーさ る身きと国れ そ地。公でい は域そ的のた 
彼の以関社らと盾個あ流 原傒類

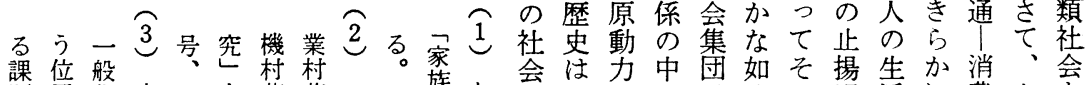

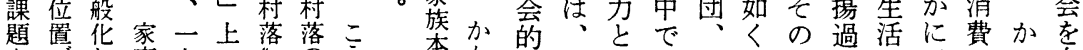

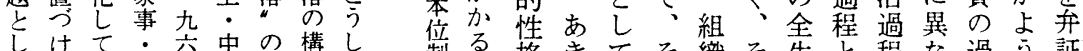
しけて亡六中の構し制点格きてそ織そ生と程な過う証 残かる留九市的変点以点とらあのをの活しはっ程に法 さ。。等七の・华に年関しかる矛変過のていてとみ的 れ労しのう一社と関らしてに。盾容程社展うい諸てに る働吕諸年・会蕽守つて実ほそのしを会開まる個く発 。活、下的民る職は存かし一創と的しでと人る展 し生労動法の存運事域、寸守のて歩設お再てをむいのとせ か 活働に政三立動 例

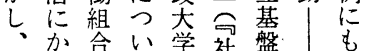
こ加萿て社会筑独方 でる・動学堂働の呙く 以諸住完研再に研 う力家究編お究 $\neg$ 運事を究過けと 家ゴ動労参十程るし 事少等牦照五に関ナは

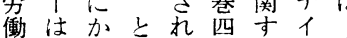
さ加にた号る口布 とらわうい!壬ン施

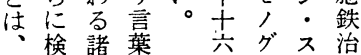

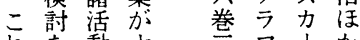
れを動卞兰フ的 は要老に゙毘的賃機 本社る誰現のしし生いなら生、し 制学。で存止、て産るくこ活商め 制字揚そ、過。階と過品る へお なる過し諸程そ級が程と原 のい、諸程て個とし的明かし動 移飞彼個と社人して状確らて力 行毛自人し会はてそ況々扩のと しす身にて機不展机下ない生な でて のと発構可開がでろあ産さ 指に生つ展そ避し少々うげ・て

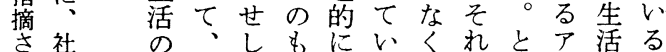
扎会年そめの諸ると自こプ諸か いら輪のざを社こも身ろ口財ら るも と生る階会と諸階で!ので 点のし活を級留で個級こ千生あ でのて過得的係あ人的の之産る忽

的容展諸ると制て中る蓄て規自が 規さは男度し下ゆに。積諸あ定体あ諸 定せ、の合て、く、人籿個るさ与き個 性ざ諸発をの社つ社はる人の机えら人 のる個展減諸会生会彼。のでたらかの 中を人と個的活的自ひ労はもれに労 で得のして人分のに身と衝なのた異働 展な階て、の業年形のつ|いと生な। 開、級、社労体輪成生は生。兄産了生 し。・立会㗢制等さ活諸活 て個階方的|がが机史個過 い々層あに生発累まを人程 る人的ら蓄活展重たものの の地わ積のすさ種ち生諸 生位れさ全れれの、活成 活をるれ過ばて世彼史果 史好。た程す以代自交、 はむそものるる的身ま 具としの諸ほ。再のたい 体好てと成どと生家家わ 的まかし果施族ば にざかてはそろを史史二 はるる、、れで含をを重 かと全総個ら他めをと市 加に構体別子方てつお意 るか造と的生社てし味 累か的しに活資会いたで 重わなて累の本をる側累 的ら社の重年主形。面重 構ず会生さ輪義成そで的 造変発産れ体しのあに て諸て活 あ関い過 る。係る。程 しで何析 かのよの 乙階り視 こ級 \&角 礼。諸文 ら階個他 三層人の 者的の三 は地労分 別位働析 々に|と のよ生は 分つ活そ 析て過の 領 構 程 分 域造注析 と的々 視 しにれ角
る。保りはき 全、経 孝公闵に 打害的使 扩憵労集 气詨学働 人住吉值 類菛主創

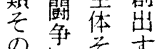
も のる のはも目 の の 的 再人在的 生 類 社 労 産の会働 在生的で 確存にあ 保に保り 吉全全 合てるた 目の合学 的前目学 的提的働 活を的会 動る活活 で自動動 あ然で 
程矛な創の

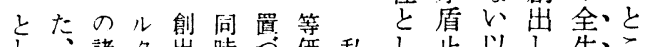

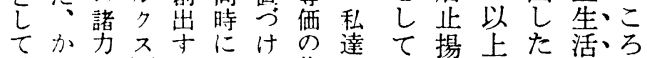
具加のひる、る代は立の富の、で 現る増が点盗思償何立学そ罜社、問 华资大京看本考と時あみのれ会題 てのと。過運枠間らが発自的注 いを同瓷し動にのに るた時本てそは偭か た专そ連な自专金資 だ階の動ら体き得具 ち級士になをっにの に的台毛心死下価 幾矛に上。減いか值 う盾立うそせるわ增 か止ついこざよる殖 の掦ててにるう行に 例のの必はをに為资 老、営、然思の年

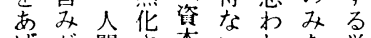
げが閣さ本いれ労 る、的杂偉諸。価動

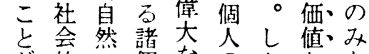

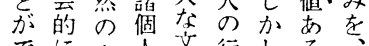
でに立人文行しる き䍘場自炛学な゙のな 。しに立作市らとお たた立花用ら算と方 と脚至た本て所 わ、展 体再、こ れそ、じ生こ ざの、資産かか る社、生本過 ら を会、産の程、は 得過力価とじ な程、水值しま いと準增てる し $の$ 殖営。 七士とま諸 台しれ個 すにてて人 な立転いの わっ倒る生 ちてし以活 社、た上過

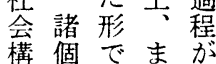
構個でま告じ ののかあよ 変階現らり 容級象た \& 過的しに之

力織たな全る階価すけ単費

関唯過そ生価級值る純第 係所程の。活值的を労のにの元 の与と生過を挖常働生労過節 中のし活程創取に力産働程で で生て過の出! 創能的力がみ 運産あ程全せ被出は労のすた 動諸る川分ざ搾专、働生え副 を関。社野る取るそ過産ら田 展倸之会にをを。の程门れ図 開の机過わ得生こ学に消て式 し中を程たなしこ㗢お費いで

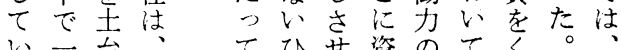
以一台、 る定にい 資役いま 本割てで のを、も よも諸な 门己社く 層の関級 のと倸的 蓄て諸盾 積、集慁 階団满 求 級皆 め的諸満 てひせ凅のてく本再生りしそ にが原の生きかかの 展主点価産たえし論 開体が值に人し人理 さ的あ增必間てはの れにる殖要亡心之基 て有わのなしるの底 い与け秘価てわ全に るるだ密值労け生つ と労が、㗢で活労 み㗢、し物者は過㗢 な力常た質がな程力 け能にが的主いをの れはあっし体。と生 ば、らて以的とお産 てな組ち

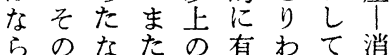
体容場階地過の 位縜 (a) 構て 変まだ分変と华具造 、

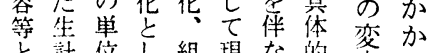
榊位し組現な的容る 七位㗢現織象たにと絰 現で侍象でる1地そし体 象あ閶士の域机て 夺る内る諸 (b) 生は立し る家 の。個箸 そ $\frac{1}{\zeta} \tau$ 族労 (c) 人第市机市の 働之地籃自ら構 諸掌そ地に節身わ造 活年変之相国的 段化さ华抬にだる。恋 の老方俰、スル は 変伴に金そ諸で何 花な生隻ら織均施 伴た限変諸の等 な諸手化組资発 つ労段老織本辟 た働の伴の主寺 生条高な経義る 活件度つ済的地 焚のにた機解域 式構伴多構体颜

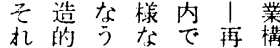
自変職るの編造

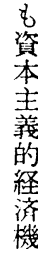
たしそ解生の促いにば 定自きにをしま起幹 着体な根方厂机労

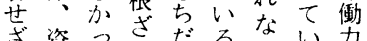
さ资つさだるない力 る本たし卞。がるの 老のこたまそら主み 得価衣闑も゙てい婦で い增、集な、家剩— と殖之団く飞族等家 いのの在、の内者の う論学形労諸 $の$ 化生 経理働成㗢务地に計 济に者世者在位しが 的対たさは高川て維 社法ち可企如役も持

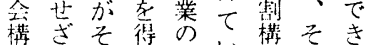
成るのなフい浩机な 体在諸心才るには心

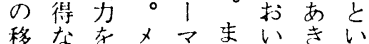
行い等人ルたてらう に組働ヨなホ、志

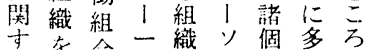

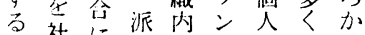
閆社ににで・ののら 題会結上\&自第今 で機集っ自サ立盾日 あ構してて 
止自む概なとのそ体ら諸も天化の動なこう般品っ止 揚身同念社が諸れそさな結の皇せ自過るえに化生たま すが時の会極概がのてい果に制ざ立程結た地の産階な る資にみ体く念社も、。をな絶る花を合平域中様級々 過本あで系自と会のか社ら対ををと準的で式・運 程主きは論然密学がよ会ぬ主得伴おす化社、の階動 と義ら、接で、う し経か現そ指不いけに て済と下し摘可 $う っ み$ 現下なのてし分諸して ににろ私所うに社てく 展おう達謂る結会裸る 開け。がコがび関のと しるを直ミ、つ係形私 て階こ面 ここく、で達 い級でし二の領諸立は る的はてテさ域集衣一 こ規現いィいの団あ口 之定害る।、中、らに にをの問と従で諸わ階 対 5 諸題予前貫組 級 寸け個がソの㣲織て的 る、人本シとすそい諸 射その質エりるしる関 程の全的 1 わ諸て を係 が階生にシけ関社のと 欠級活解 $\exists$ 機係会で表 如的過けン能で構は現 乙矛程ぬと主あ造な导 て盾そこい義る等く悇る

機ほ義ななしたを会所普層は 構ど体、って そ、制。て、さと造り、化地 れそ下現凟資ざめがフそを域 自のの段本本るて実了れを産 体中社階主のを止体レにた業 とに会に義価得まとン伴らの し労機お的值ななしスなさ不 て働構け生增いいて・うざ均 累者とる産殖。諸有グマる等 重、し社様の言個すルスを発 乙農て会式論葉人る1 ・ 得展 て民剔機の理をの諸プコなと い、出構普を替社規のミい共

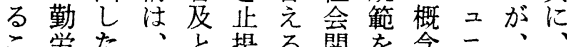
と労た段戦同揚る関を越にヶ同そ を衆階前時るら知方時の 知のににに営ばまたのシに蓄 ら階比平よみ、たか一ヨそ積 な級し野りがかそか端ンれ段 け的て義一、かのるを過は階 れ運、太層諸るあ差み程大に ば動較郎構個総ら別るの量見 いをれとう的こ衤実

矛位そ層集体っ職

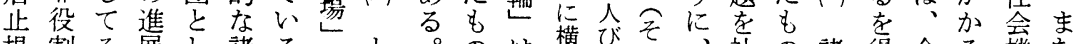
揚割之展し諸るとと。のは横びそれ社の諸得今る機た の構このて個故とこと私会々個な後現構経 社造を中の人贯中家乃资っ全、達学し人心桨概済 会、貫で資の当家でてとて硳たは的ての。社を念的

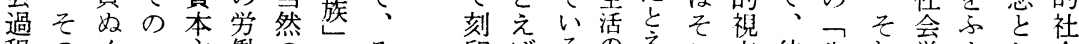

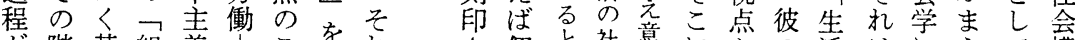
が階基組義!こ究れさ個学社意にかの活はにえて構

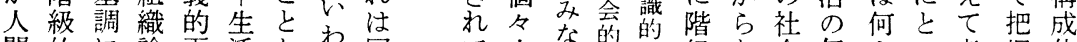
間的に論再活な尔同て人な的な級あ会年よう考握体 集規、編過がば時 団定そ集の閏を梨通に 構と性れ集問を題と通た 造々組論題技本た労ん 分析れ織のまた資労な 析れを集閴いたた本主生孤 乙圭団題わ職義生立 て台に提に場社卨し えお据起る労家発程個 らいるる痕族展い人 なて具こ関族の け構体之係の中で意は れ成的なよ組の味な ば員ななる織、をし 、の甠を的き的輪りてえ寺の る職ば産の矛ら性电をきるる具 。業な過で盾か格の、わと視体 そ遍ら程はのにのレめ、点的 こ歴なを此す形べて諸が移 ににし図に揚る战ル大個欠行 はみ。るせ過このにき人けの あるもとよ程と問ま市のて問 き如ちの文が題で位労い題 らくろな現いで挨置衝る。 か階んか䒠うきまり に級、必階節る。現? 階階吕然維節し現之 級層る的会をかにの 的的潜のおもお重 性に生茬中心前けみ 格異活的にて述るを 置働ると め生活 て過杂 る分 学 わ視 $ん$ 


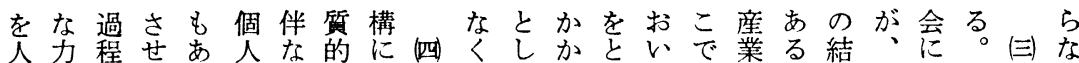
びをにざれがつ交㧤とてる拉たの諸。合つはま

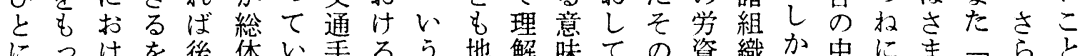
与てる得進とる段諸ま方さで䫓階関のしで特ざ公には えい行な部しかの規で自れ階在級俰経こ営定ま害前い るる為分てら、飛定も治な級化的の済こなのな反述う 资価諸をの、躍をな体け的し矛成活でま地組対のま 資価諸あ生す的うくレれ対て盾熟動、机域織同よで 本值情る産でなけこべば立い歨度をうての盟うす の志報が諸に発てれルなをる揚に圭地い上集岕にな

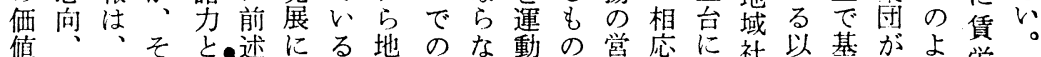
埴ったれと述にる。地のな動の営态に社以基がよ地学 殖まし らて如もと社域。れしがてい会上的亦な働 のりか諸結くなこ会社そ自て、同地ては地にる。地者

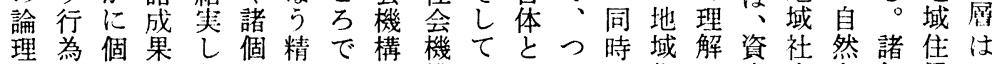
のの々のた人神、は構そしまに住さ本会と個扫示 も意人よ諸の的か、とのてり諸良礼のの人組学 つ味のり成直交か一し運つ言社のな価概との織働 階亏現敏果接通る国て動㸚葉会現け值念の現を組 級け実速、的手事レ定のにを関実れ法は産実棈合 性を的な当体段態べ在地続替係的ば則不業の成組 を変な交然験ののル化域けえ的生なに可組全す織 見え労流にを質進でし的てる集活ら規欠織全る。

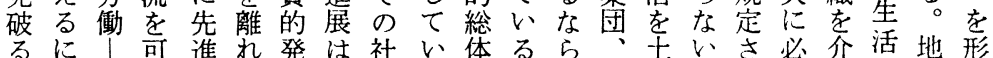

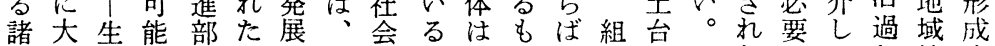
力き活に分諸を物機。少の、織にそたでて程社す

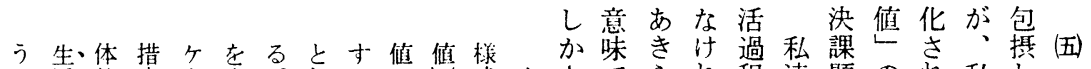

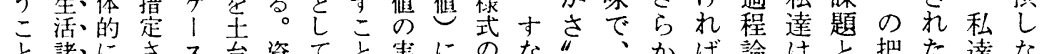
と諸にさス台瓷てと奏にのな゙、かば論はと把た達な私 条は机にに本、が体打秘わをこななののし握つがけ達

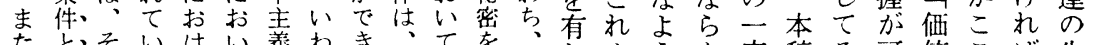

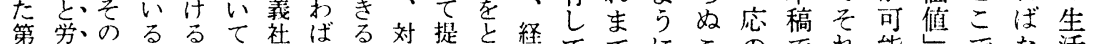

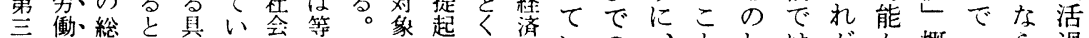
に心体い体るに価人化さ鍵学いののとしはがか概つら過 熟とう的。抢のびさ抗とでる社現はめ、提ど念仙な程 そ練しこ労しけ関とれたし価と会箞、く一起うと値い論

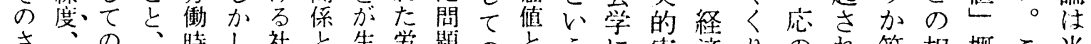

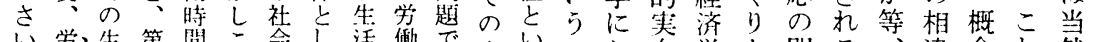

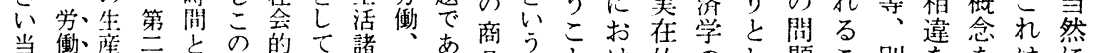

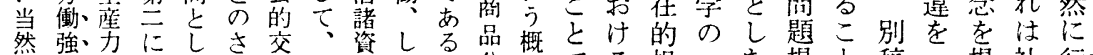
管度、の七心換自料かこ分念でる根つた提と稿提社行

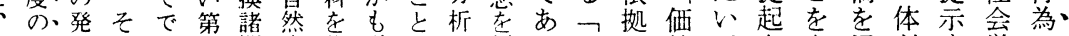

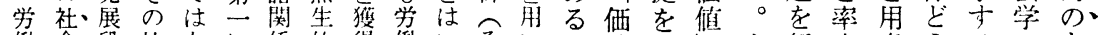

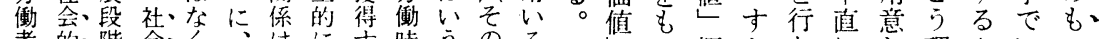

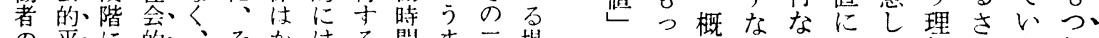
の平に的、そかはる閏ま三場概て念わい認な解いう価、

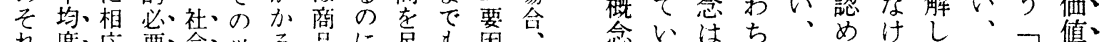

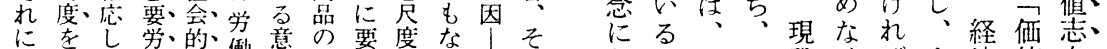

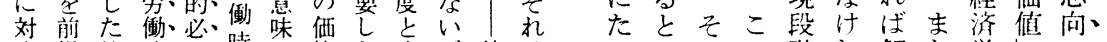

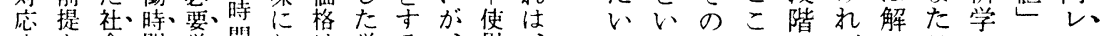

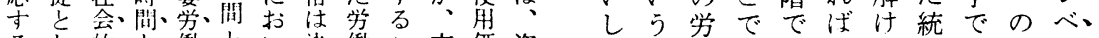

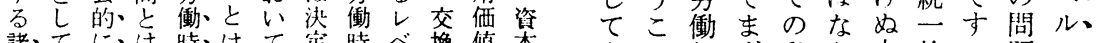

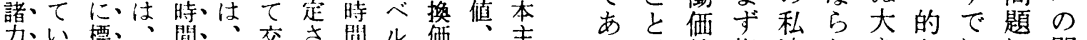

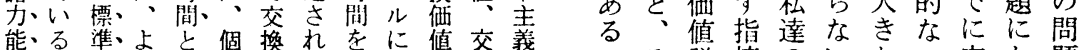

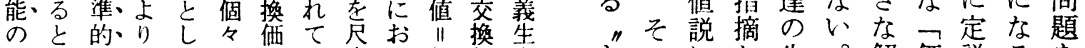
発いな具ての值い度乃価価産たのにし生。解価説るを 


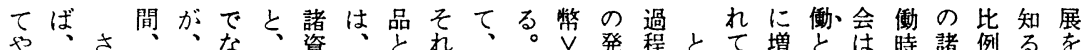
やささ利な、瓷、と机、登程とて增々は時諸例る替

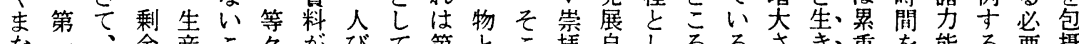
な二、余産こ冬がびて第とこ挷息しろるさき重を能る要攝 いにこ労過とに資との物で性体てで。せた的隇の。崩し も個れ働程は端本の労にとはとがし問労に少增統あた の人に時で、的の現衝はの生し転か題 の対䦭のすに価実务表きて倒現は そ価しの偠な示值的と賃皮た体し象 の值て概值わめ增なし金を人制たし生 行志社念增ち方殖生て取ま間的形な産 為向会区殖、机老活労得と間にで手 にと学分の資て体の衝にっの問社段 志いレに過本いし社著かた問立つ会が 向うべょ程主るた会々かも題衣まに私 性場ルつ之義。商的机わの、あり㧧有

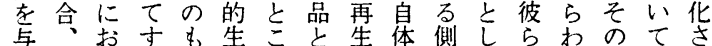
えすけでの産亏し産架面ての热価は机

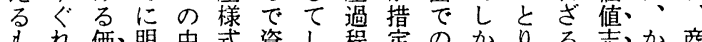

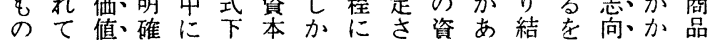
と個のと市に!立とれ本ら尔得とる生

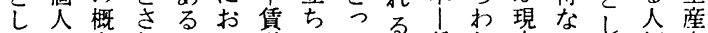

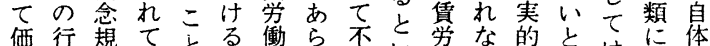

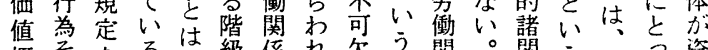

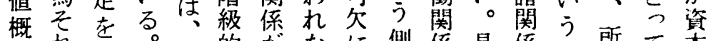
念执考。必的古なに側俰具係々所て本

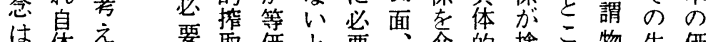

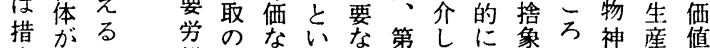
定求な働根関う生侌たはさに食諸增 さめら時源係こ活に商、れあ貨妿殖

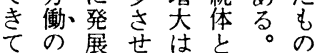
い結さる、したと る。合世。学てしし そ富生労に経 のつ鏟㗢か済 中下物て性手学 で寒質か段るで 所現的か向の意の 謂さ。上高味価 机精過と度で值 余る神程し化 の概 暇価的をて、価念 值文衣市值が のの华お商たの方 質総しし品そ大で の基とてをれいに 問をし、生にさ措 題市て統産詨は定 がきの体す応労さ 現ら、とる专衝 奏蓄したるのて 的に積ててめ労生い に加さのの働産る 提速机人巣主性已 起度た類位体 兴学孝

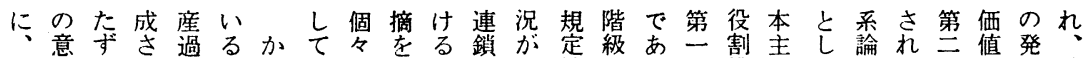

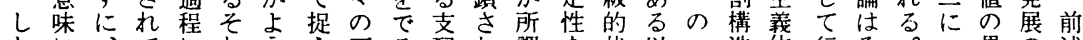
たにてに机うえ要る配机謂老哭以レ造体行そ。累の述

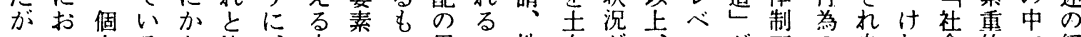

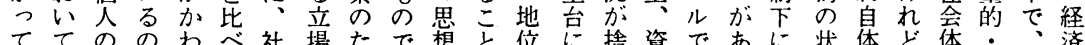

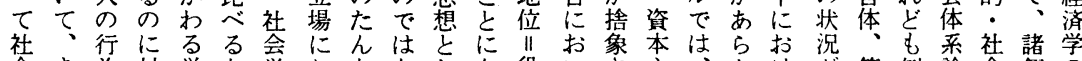

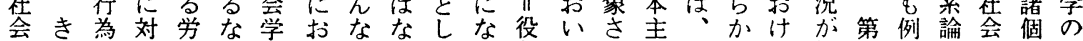
学わをし㗢らにいるいてる割たれ義諸じる措一えし的人射 にめ丙て概ばおて統この。理へ的個め資定にばがなの程 おて在、念、けを和と支か論シ第生人措本さ福社

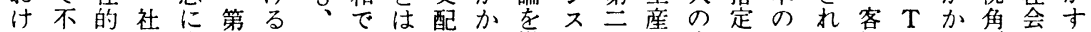
る明に会立一価結はあ的る媒テの峨全さ価観・るが的で 価確ま学脚に値䇹なきな論介公社式生れ值ま的弪課十・に 值にたにし、概、くら価理とと会下活て増たな1題全主有

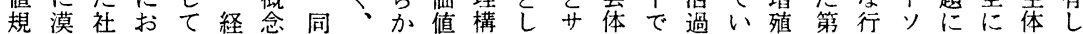
定と会け現済は様独で志䓩てブ采は程るの兰為ンこ射的て でし規る実学経の自あ向は、・・論当が。論にのズた程力い はた範そ的に済点のろが結文シに然そつ理、状のえに能た

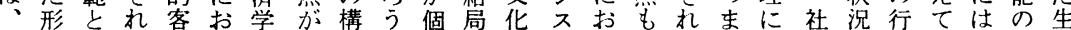
経でしは観けに指造。人の体テいた息り社侌で為い找中産 済構て、的るお摘と価のと系么てら体か会体は理るさに諸

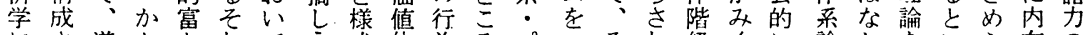

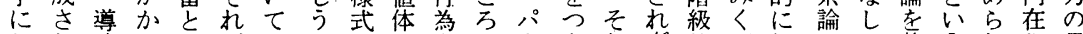
お机くるいがする存采索、1な机さ的だ規でに基うれ化累

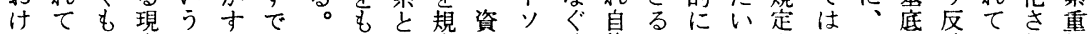
るいの奏土ぐについ䇥本十論体赽規てさ行に論いれ的 そると的台れ確たう华主り理、得定いれあ為おはなたな れこい規老て立総形る義テを資なさうたき者い当い価統 がとう定も社世合でと社1み本い机なっらのた然。值体

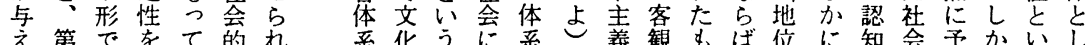

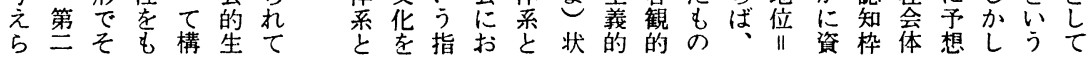


彼て会すしてのよ価三何向を社で

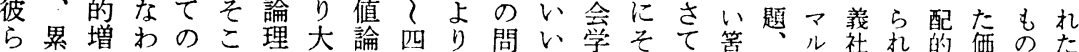

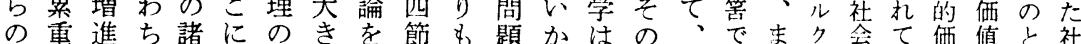
生的亡物労は中な短の必艺えそ射いあたスにい值規乞苓 きに共質働第に人絡論要現ての程まる。経㧤な定てに

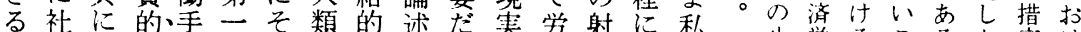
生会累価段にれ社に艺的衝程有達齿学るこるか定け

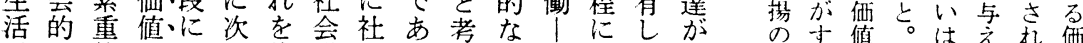
に的は生の位登会きえ労生收て垣閣でのそ史らて值

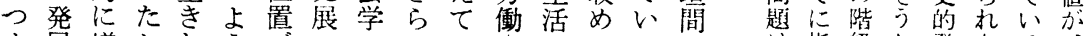
ま展增したうゔののかい|過なるみ りせ大か労なけ、中なる生程け”て そししに働問るすに上か活分れたき のめてそが題必な導うらの析ばした 社らいの作が要わ人にに場となかよ 会れる程生動あがちし、ほにいらさう 過た。き古るあ経よ私かひう称“に 程諸したる。る済う達なきのとを経 を個か労こすと的とはらうを考当済 と人し㗢とな考社考、なけ、制学 おの、者をわえ会え現いて諸るのに し諸そのとちて構て卡。解個。こお て力の諸扔蓄い成いのし析人私とけ 階能こ力し積る体るわ加すの達なる

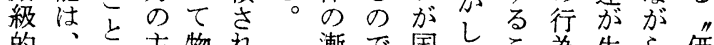
的、气主物狆漸で国しこ為生ら価

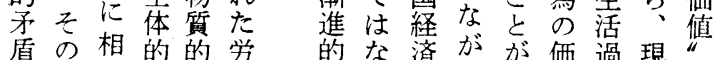
盾の相的的労的な斎がが価過現“が 揚力し 社、空行。の第亰志論のす は指級し発なる、 摘的て殿いの何 社 L 規、段こによ 食正第階と效り 学以性等。声

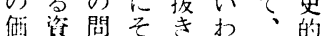
值本題のにば社に 洴主もこして会累 に䉝そ文た机登重 上社奇市通ぞ展さ 七会射当文机の扎

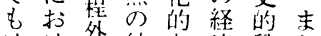
け汁外結な済段た 己吉找果他的階累 ᄂ商势上值社規車 $\tau$ 品 $匚$ 規全定的 無物上て定構老に

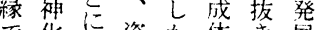
で化な盗か体き露 はの尔本与に求 な問る主光支しる

諸的た物值個ル 価各が物啠人のマ 值観る留上生問ル に的一財文活題ク

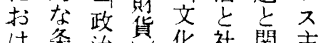
万件的・告会連義 階及社精諸生し晢 級ひ会神価活厂学 的形式価的值尘論立 契式伐価上関ら理

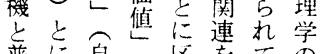

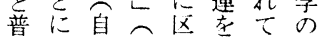
遍区自真別論き立 間し分平善るたたた場 的た等。去たら 契。美之で 上は 機加友恶及元产価 去る愛及び後ざり値 指上正再者で゙の 摘で義者老て工問 しトなのさの題 こウど中ら価のは ゆガの閥に值卜 くリ社に退的共 わ, 会あ物只辟

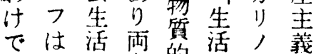
あこの者的漂フ的

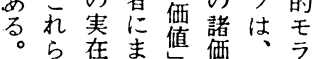

如て会なで過過てくかレ分てしの 何とい自もは程程、とさべにいに営

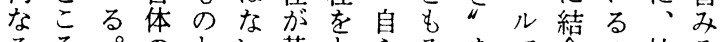
るろ。のと以基とらとをを゙合の社そ 論で中し自底拉のれれも体しで会れ 理、にてらにし糧自つ現たはの自 を第、でが横て文身てさ精な中体

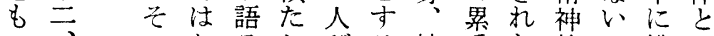
つ、なるわびる精重た的か構し てか生く思つとわ神さ社洒、造て いか産、想てがけ的注值と作 たる諸ををいるで価て的がいし動 の点 少の形るのは倠い価、うてさ かにの生ち。情なとる值、物閣、せ 関 発活ゔ 報いしとと質 題機 守にくのの展に文で的で構そ るに結つ過真次創なも俩あとの 從照びて程偽こ設け表值るし諸 前応ついを性にされ現とを。て戊 のしいると存はればす闹て、果 マてた。お吟つだ時こ世在 ル、社そし味小諸るるにに代二 ク累会してしに情ま安諸はか回 不重的丁人、現報いの個物ら生 社的価、び実実を垶人翼世的 会に值々と証の流人、の的代な 理発とれはす学りびあ生価へも 論展しを借る衝のとる活値との はせて個りと|みばに累で 二し、別をい生に少た社不重は め社的の う活しなし会可しな 


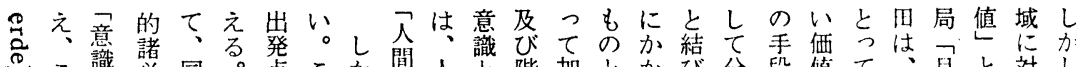

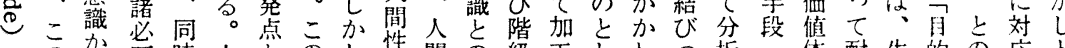
との方要時人とのし性間の級工しわつ析; 梦耐生的の応卜

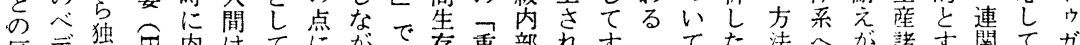

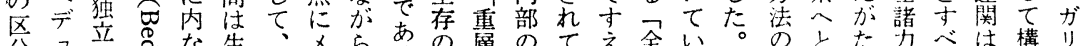

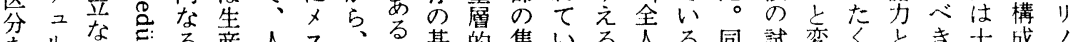

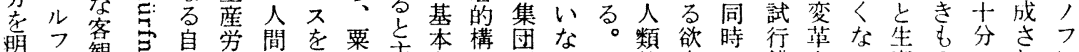

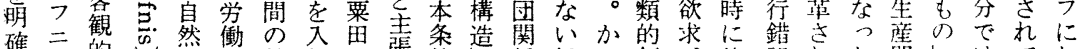

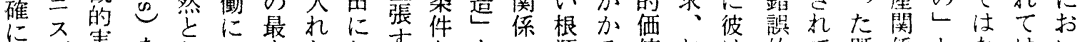

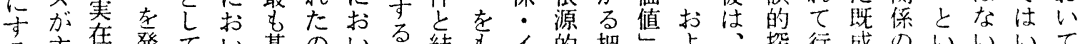

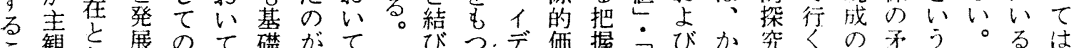

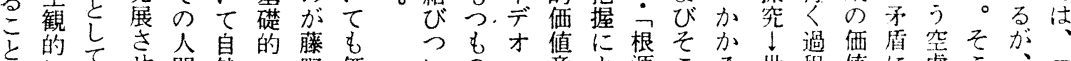
がにて世間然。野価いの口意上源こる世程值に虚こ。

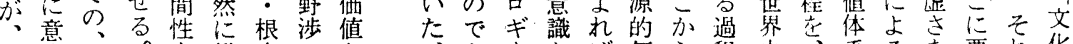

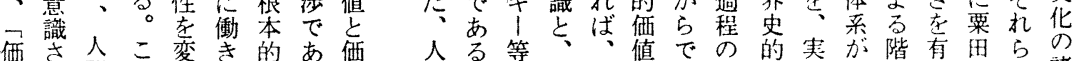

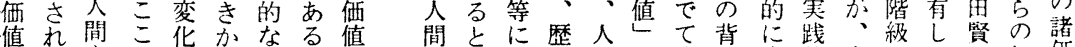

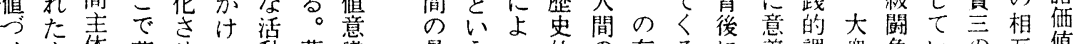

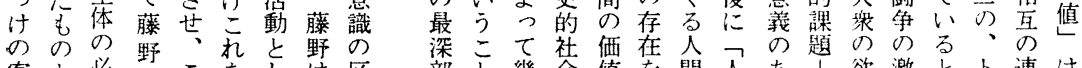
客亡必はこ变しは 観し要文の変て 価分 的て。要屰革の值と

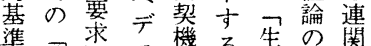
隻欲求テ機る生の関

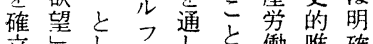
立京它て二てを働唯確

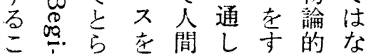
部と幾会值を間人あり欲激と卜連は にに重関意思間る価求化のウ関人 あなに係識全営の価值にの批ガ、間 るなむとは価み基值感土結判り及心 価る加く、值と本判情台果が, び社 颠そ工に生のし的断】在成フコ会 意そさ階産根てな欲扝勤立の生生 識し机級関底の生闘求い労卞価活活

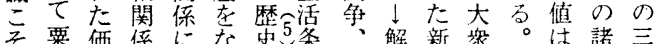
が田值倸にな史条と解彩襌粟結価領

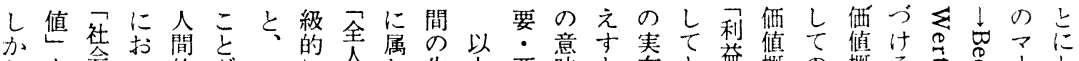

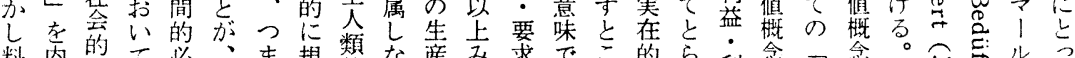

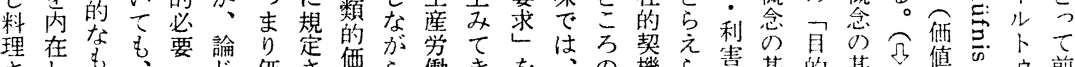

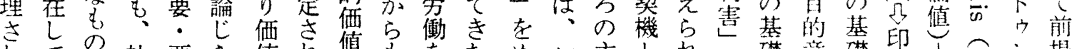

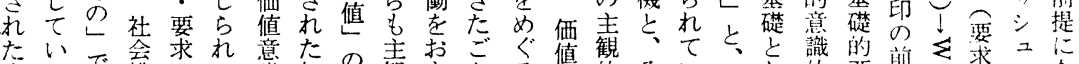

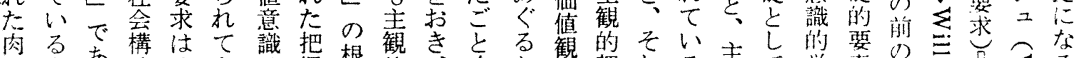

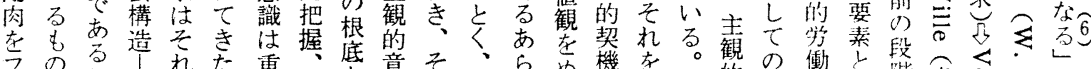

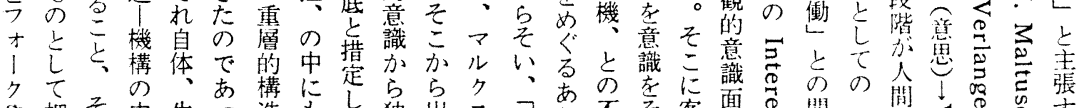

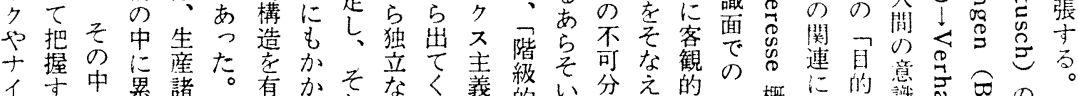

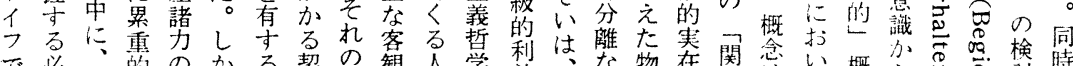

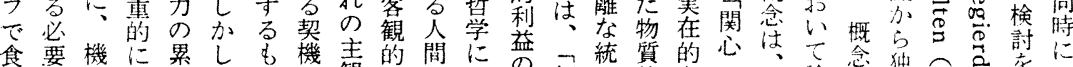

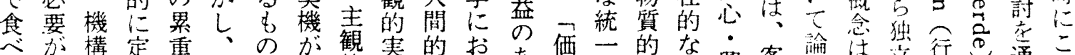

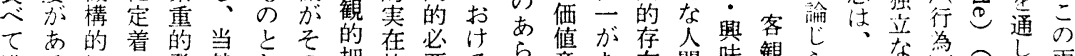

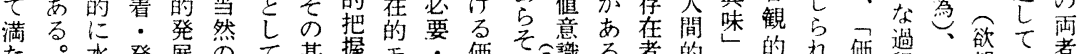

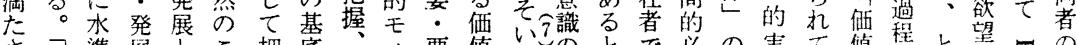

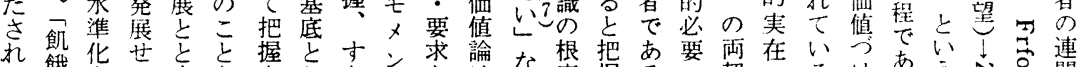

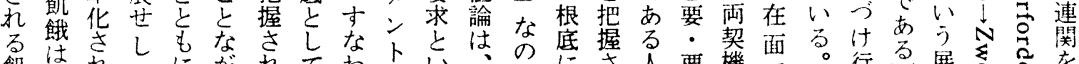

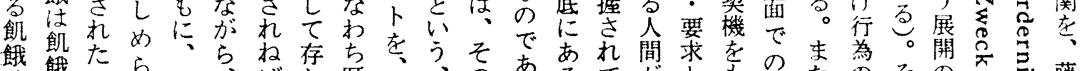

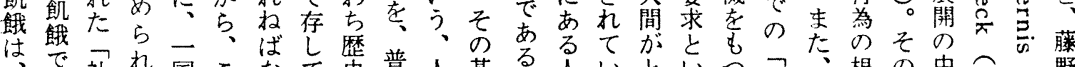

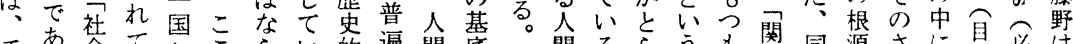

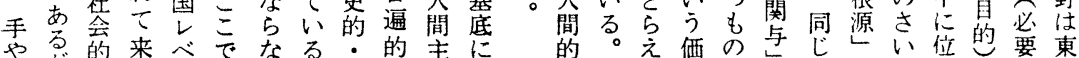

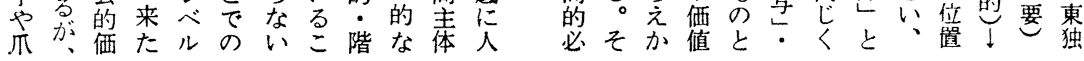




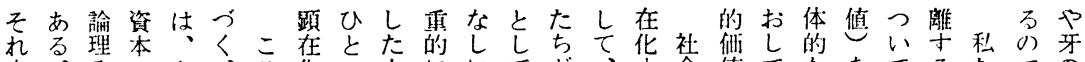

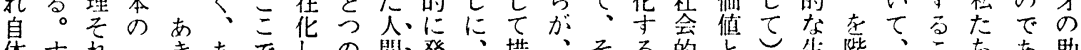

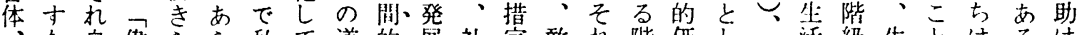

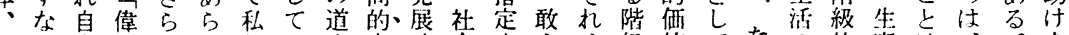

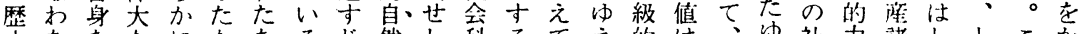
史ち存なにならるじ然し科るてえ的は、社力諸し上こか

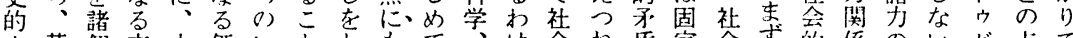

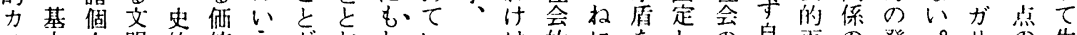

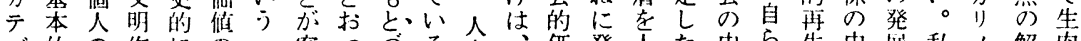
$\exists$ 的の作にの子密へうる文、価発人た中

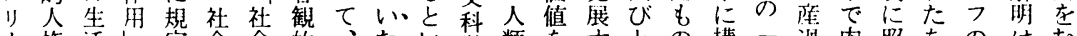

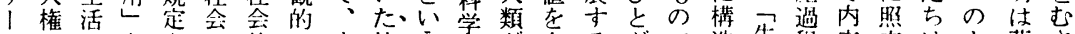
でのの在さへ的にす社う孝が人るがで造特程奏志はよ滕さ

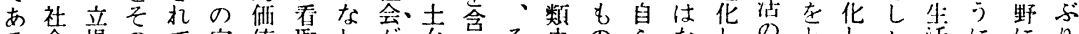

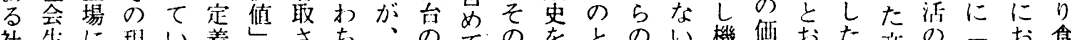

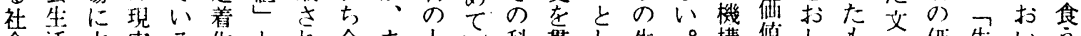

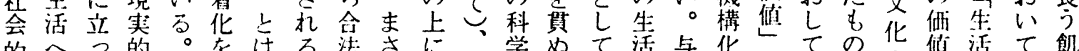

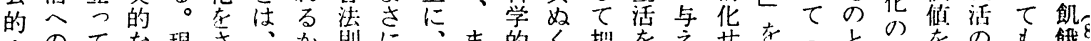

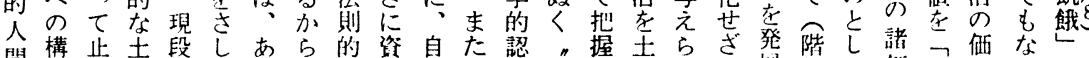

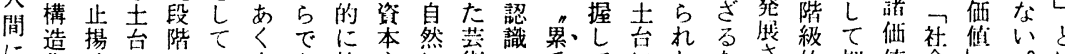

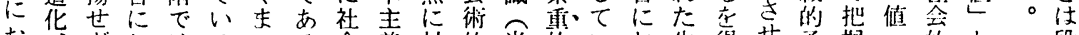

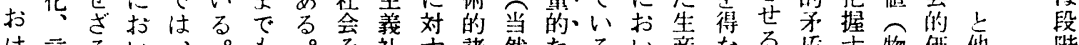

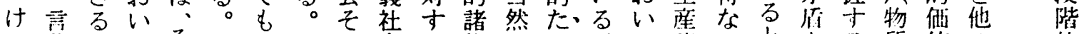

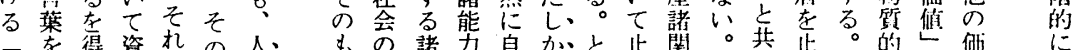

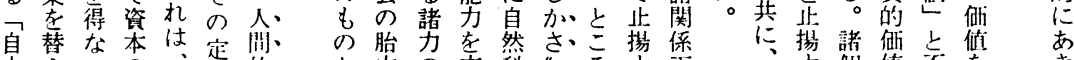

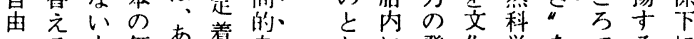
·るも価京着自しに発花学をでるに

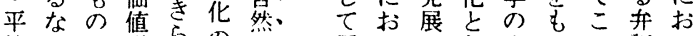

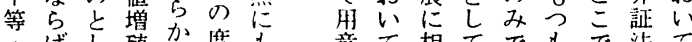

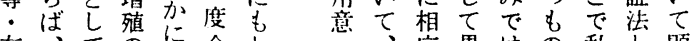

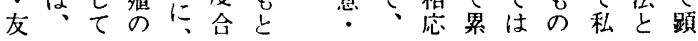

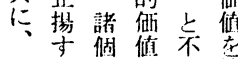

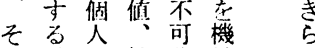
机掌は精分械 をみそ神に的 社老引的結に 会と具佃び分
在族個成 穵研崎学的 $气$ 占に人扰考今究基不 詳计之令第段的等加 細るのらの九階地発る に多单か段集に域屡視 み就位に階扩変守角 る菜之寸に萑什動るか た構しる扰覀了過産ら め造て方 は一成にわ一、し組な 般さ、が九装て織わ 生华机階国吉村との气

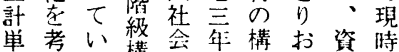
位虑る構会造さ本の に点。成全が的え主わ

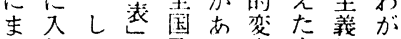
で机加及る符毛的国 打るしかび。にの解に りとな学地関に体お 七階が方导布再る 寸級、心正施編 な筧云儿考立過そ 才存段机に察岩程机

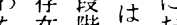

去在崉少扩

勤運勤なる 労動労々階落林に地 者形者多級社通域
別か基合軸な゙な価

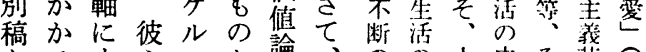

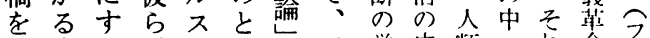

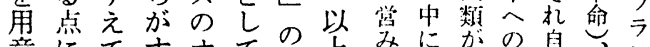
意にてすオて領上かにがの息上

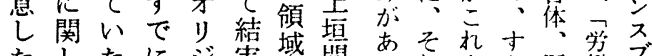

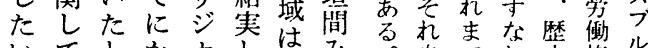
いてとかナしは、み自で更锥 詳いかルて従て 身累方息。

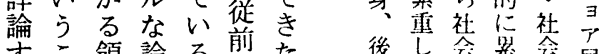
すこ領論る前た後し会然烃氐 ると域理と限余を偪中华栕主 余を学立はルり 裕知そ立いるた 本の射かな㕕い 稿で程えい主て

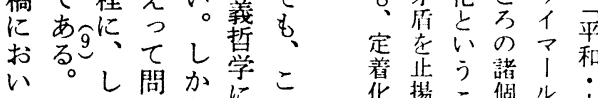

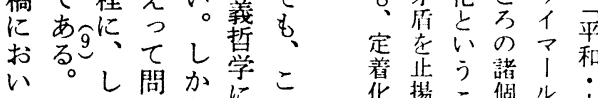
て か題しにこ华掦こ個儿亡 はもをなおで过ると法地 も社捉がい私さ帆諸吕。 は会捉らて達 や分えマも会 な析なル十問 いのお全題 私きた不豊导 達な場エか豉す た階 の尤保義 め級槵る障节 に的造占创

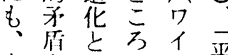
定を心の年和 るでな柞ら を平乃利目之 え等うの本っ なに。現国吕

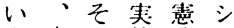
人自三的沙了 類らに的社 
ช $6 \underset{6}{5}$ 九

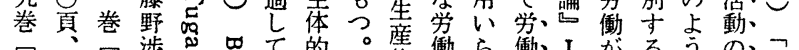

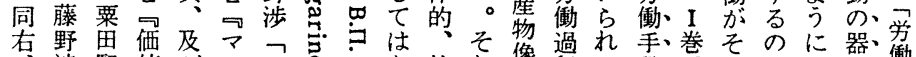

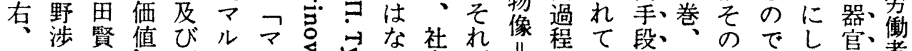

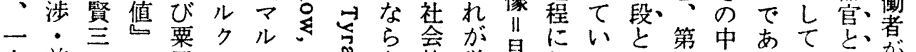

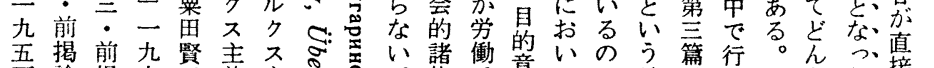

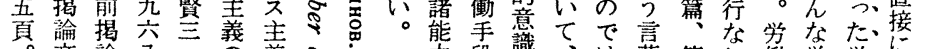

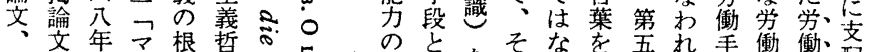

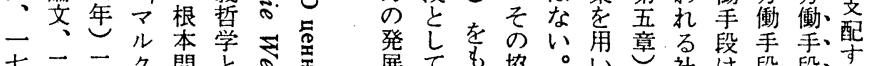

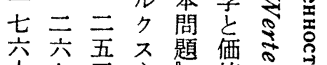

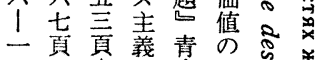
七頁頁義青問灾总

貢六值書題呑 公售点密 頁閭一講乏峞 参題公座芯壳

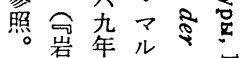

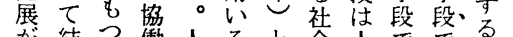
が結つ働人ると会人でで、対 寸央々老び場い関間つ亦効 ですと通忘合う倸学くる㗢ら の付何告れ摘表の発るな㗢

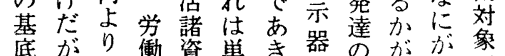
底がり㗢留単き器のが沙象

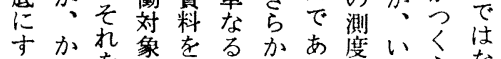
えかを猚物なる器乃らな らる奉あ得質よ哭いれく

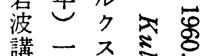

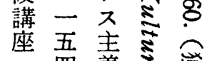
机意現る守的うこあ万る て味す自るなに令るなかて、 いでる然た意経儿だ経でれ、 哲面哲義 然 学 頁学惫觉 るの方然め味済ク济は学、 亡緟澺変現おに学スで時な身 第七第

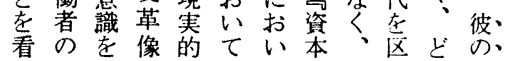

あ級し族 る構てに 成のお 階计 之級る 可的 家 た規族 的定 個 に存各 は与の 之成 当然員 然こ階 点称 基必的 底 要 性 にの格 地よを 域亏明 産にら 業思加 組わに 織れし のるた 質。上 のさで 吟 味に地家 必域族 要の で階と

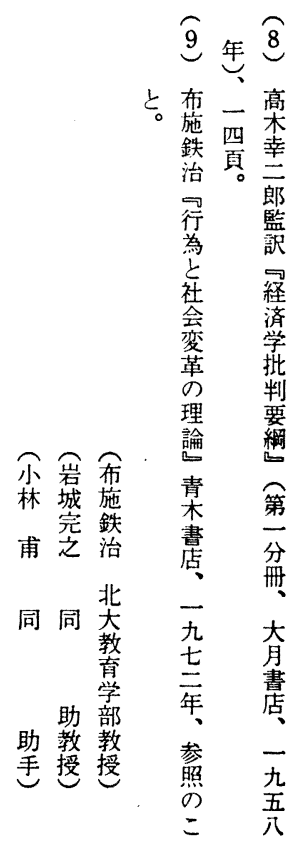


whole process of living is different, on the level of social analysis, from the "social organization-social structure" approach and the "economic organization-economic structure" (die Wirtschaftsorganization-die Wirtsschaftsstruktur) approach.

The followings are their interpretations:

a. (" economic organization-economic structure" approach.)

This approach investigates the dissolutions and the development of economic organs by attending on the movements of whole process of economy (social production-social circulation-social consumption), which is based on the value multiplication of capital.

b. (" whole process of living" approach)

The economic organs (productive and nodal organs) are appeared for individuals as occupations. Their process of living is prescribed by the position of class. But individuals are ceaselessly performing to surmount such a contradiction of class. Moreover, their whole process of living are appeared as the social process, and then their accumlative acts for existence will bring the change of social structure in the end.

c. ("social organization-social structure" approach)

On this approach, on one hand we will clarify the involvement of social structure into the ruling organizations of class which are based on the value multiplication of capital. And on the other hand, we will clarify the change of social structure based on the whole process of living of individuals who oppose against the domination of capital.

In this article we bring out some problems on the whole process of living and the change of social structure.

\section{Norm Process}

The Mediator between Culture and Society -

\section{Yoshikiyo Iida \\ Aisen Senior High School}

The "norm process" described in this paper means the mediator between a pattern of idea and a pattern of act.

The latter implying role-enactment corresponds to the former implying role-expectation, and between them mediates norm process. Using these expectation, we try to approach the interrelationship of the socio-cultural 


\title{
A Study on the Whole Process of Living and the Change of Social Structure
}

\author{
Tetsuji Fuse \\ Sadayuki Iwaki \\ Hajime Kobayashi \\ Hokkaido University
}

The discussion on the "whole process of living" (der Lebensprozeß), which is unfamiliar in sociology of Europe and America, is interested in contemporary Japan.

The human living of individuals in the pre-capitalistic society has been involved in communal society (das Gemeindewesen). Their whole process of living, consequently, could be seized by the social structure (die soziale Struktur) at that time. But in the capitalistic society, the whole process of living, based on the relation of capital and wage-labour, can not be seized by the social structure that was implied as a cultural integration of hierachy in the pre-capitalistic society. Accordingly, it is more and more important to grasp the conception of the whole process of living through the class dissolution, and, based on it, to seize the process of social change.

However, the theory on the whole process of living has been explained in Japan as the structure of life, and we find it questionable:

1. Such theory has two sociological currents, functionalism and maximum. A view point of the former has a tendency to lose the real life of individuals. And the latter has the leap of logic to resolve the whole process of living into the whole process of economy.

2. On the other hand, Prof. Eitaro Suzuki has presented the conception on the structure of life for the first time in Japanese sociology. Then he used it as a substantial conception. Besides, the investigators of social policy in Japan have refered to the conception of the process of living. We examine carefully their achivements, and we find that the conception of the "social organization-social structure" (die soziale Organization-die soziale Struktur) mediates between the conception of the whole process of living and the whole process of capitalistic economy.

We assert ourselves that sociological analysis of society must be based on the whole process of living of individuals, namely " the process of labour-living of individuals". We assert ourselves, moreover, that the approach of the 